\title{
38-Resimli bir seyahat romanı bağlamındaki çokdilliliğin Türkçedeki çeviri serüveni: La Femme et Le Pantin, roman espagnol
}

\section{Ayşe ÖZKAN ${ }^{1}$}

\section{Osman ÇEVİKTAY²}

\begin{abstract}
APA: Özkan, A.; Çeviktay, O. (2020). Resimli bir seyahat romanı bağlamındaki çokdilliliğin Türkçedeki çeviri serüveni: La Femme et Le Pantin, roman espagnol. RumeliDE Dil ve Edebiyat Araştırmaları Dergisi, (Ö8), 471-489. DOI: 10.29000/rumelide.821916.
\end{abstract}

\section{$\ddot{O} \mathbf{z}$}

$\mathrm{Bu}$ makalenin amacı, resimli bir seyahat romanının içerdiği çokdillilik örneklerinin Türkçe çevirilerini çağdaş çeviribilim yaklaşımları çerçevesinde incelemektir. Bu amaç doğrultusunda, Fransız romancı Pierre Louÿs'un 1898 yılında kaleme aldığı La Femme et Le Pantin, roman espagnol adlı romanının dört farklı çevirmen -Hasan Bedreddin, Ref'i Cevat Ulunay, Tahsin Yücel ve Mehmet Doğan Özbay- tarafindan 1922-2012 yılları arasında Türkçeye yapılan çevirileri incelenmiştir. Kaynak metindeki çokdilliliğin erek metinlere çevirmenler tarafından nasıl yansıtıldı̆̆ı araştırmanın ana konusunu oluşturmaktadır. Başka bir deyişle, çevirmenlerin kaynak metinde özellikle Fransızca-İspanyolca arasında gerçekleşen "dil değiştirme” (“code-switching”) durumlarını Türkçeye çevirirken hangi çeviri stratejilerini kullandıklarının araştırılması hedeflenmiştir. Bütünlüklü bir inceleme yapmak üzere, Harf Devrimi öncesi, 1922 yılında Hasan Bedreddin tarafından yapılıp Akşam-Teşebbüs Matbaasında basılmış olan Osmanlı Türkçesi çeviri de araştırmaya dâhil edilmiştir. Osmanlı Türkçesine yapılan bu çevirinin daha önce çeviriyazısı yapılmamıştır. Bu makale kapsamında anılan eserin çeviriyazısı yapılmıştır. Ayrıca, tüm çeviri metinler üzerinde çevirmen kararları ve dayanakları odaklı karşılaştırmalı bir betimleyici çalışma gerçekleştirilmiş ve ortaya çıkan çeviri olguları tematik olarak sınıflandırılıp tarihsel bağlamda değerlendirilmiştir. Betimleyici çalışmada vurgu noktası olarak Lawrence Venuti'nin, Friedrich Schleiermacher'den esinlenerek ileri sürdüğü "yerlileştirme" ve "yabancılaştırma" (1998) kavramları temel alınmıştır. Bu betimleyici çalışmanın, resimli seyahat romanı bağlamında sergilenen çokdilliliğin Türkçeye çevirileri konusundaki tarihsel bakışımıza katkı sağlaması umulmaktadır.

Anahtar kelimeler: Çeviribilim, çokdillilik, seyahat romanı, yerlileştirme/yabancılaştırma

\section{Turkish translations of multilingualism in the context of illustrated travel literature: $L a$ Femme et Le Pantin, roman espagnol}

\begin{abstract}
This study aims to investigate the Turkish translations of the elements of multilingualism contained in illustrated travel literature in terms of modern approaches to translation studies. For this purpose, we inspected all Turkish translations of La Femme et Le Pantin, roman espagnol written by Pierre Louÿs in 1898. These translations were made between 1922 and 2012 by four different
\end{abstract}

Dr. Öğr. Gör., Yıldız Teknik Üniversitesi, Yabancı Diller Yüksekokulu (İstanbul, Türkiye), aysemilo@gmail.com, ORCID ID: 0000-0001-5724-6202 [Makale kayt tarihi: 10.09.2020-kabul tarihi: 20.11.2020; DOI: 10.29000/rumelide.821916] Öğr. Gör., Yıldız Teknik Üniversitesi, Yabancı Diller Yüksekokulu (İstanbul, Türkiye), osmanceviktay@gmail.com, ORCID ID: 0000-0001-9550-994X 
Turkish translations of multilingualism in the context of illustrated travel literature: La Femme et Le Pantin, roman espagnol / A. Özkan; O. Çeviktay (pp. 471-489)

\begin{abstract}
translators -Hasan Bedreddin, Refi Cevat Ulunay, Tahsin Yücel and Mehmet Doğan Özbay. The study mainly aims to discover how multilingualism encountered in travel literature is rendered in the works of translators. Namely, it is aimed to discover the strategies translators employed while translating into Turkish especially the French-Spanish code-switching cases. To have a more integrated approach, the translation made by Hasan Bedreddin into Ottoman Turkish and published in Akşam-Teşebbüs publishing house in 1922 prior to Alphabet Revolution was included in the study. A transcription of this Ottoman Turkish translation has not been made before and it was transcribed into modern script in this study. Furthermore, a comparative descriptive study was conducted on all translated texts focusing on translator decisions along with their supports, and resulting translational phenomena were thematically classified and evaluated in a historical context. The descriptive study was founded on the terms, "domestication" and "foreignization" proposed by Lawrence Venuti (1998) drawing on Friedrich Schleiermacher. It is hoped that this descriptive study will add to our historical look on the Turkish translations of multilingualism displayed in the context of illustrated travel literature.
\end{abstract}

Keywords: Translation studies, multilingualism, travel literature, domestication/foreignization

\title{
Giriş
}

Seyahat yazılarının çeviriyle dolaysız bir ilişki içinde olduğu, hatta bunların da çeviri olduğu ortaya konmuştur. Seyahat yazını özellikle diliçi ve diller arası çeviri boyutlarıyla (Cronin, 2000) vurgulanmıştır. "Her ne kadar dillerarası çeviri seyahat metinlerinin ortak dili olsa da, dilsel şeffaflık yanılsaması yaratma amaçlı olarak buradaki çeviri yazar veya eleştirmenler tarafından sıklıkla gizlenmektedir" (Cronin, 2000:3). Ne var ki, seyahat romanlarında yabancı kahramanın okurun ana dilinde konuşmasının yanı sıra roman yazarı bir taktik olarak seyahat bağlamını kurabilmek adına hem anlatıcılara hem de kurgusal yabancılara ana dil dışında sözcükler söyletir. Şu durumda bu çalışmanın konusunu oluşturan romanda Fransızca kaynak metin bir İspanyol romanı alt adıyla tanıtıldığı için bir seyahat çevirisi söylemi olarak görünmektedir.

Seyahat kavramının da sanal hale gelmesiyle kültürlerarası "temas bölgesinin" artık devasa bir boyuta ulaştığı günümüzde kültürlerarası aktarım yapmak için sınırda olmak, sınırdan yazmak, sınır geçmek gibi bir gereksinim kalmamış olup, artık kültürlerarası ilişkiler ulusal kültürlerin iç yaşamına katkı sağlamaktadır. Dolayısıyla ister sömürgecilik sonrası yazınsal metinlerde örtülü biçimde olsun ister çeşitli "sınırdan yazı" kiplerinde apaçık bir ilham eseri olarak olsun çeviri ve çokdillilik (multilingualism) birçok çağdaş metinde kendine yer bulmaktadır (Simon, 2002:71).

Hem çevirinin hem de seyahatin genellikle akış ve hareketi anlatan eğretilemeler şeklinde görünen eylemler olduğunun ve çağdaş "postmodern" toplumun küreselleşmiş doğasıyla yakından ilintili olduğunun farkında olmamız gerektiğini söyleyen Polezzi’ye (2006:175) göre ise, "çeviriyle seyahatin arasındaki ilişkinin kazandığı soyut, ikonik niteliğin farkında olmamız bizi bu iki eylemin gerçek aktörleri, eylemleri ve eyleyicilerine odaklanmamızı sağlayacak yöntemsel ve etik soruları sormamızı engellememelidir”. Bu uyarıdan sonra Polezzi, kültürel ve sanatsal üretimlere batılı yaklaşımın baskın olduğu budunmerkezci yaklaşımları çürüten postkolonyal araştırmalardan örnekler vermiştir.

Ne var ki, çokdilliliğin çevirisi sadece postkolonyal araştırmaların gündeminde değildir. Postkolonyal dönemin sonrasında edebiyattaki çokdilliliğin incelenmesinin 1980'lerden itibaren ivme kazandığını belirten Reine Meylaerts'e (2013) göre, çokdilli olma halinin çokdilli metinler, insanlar, kurumlar,

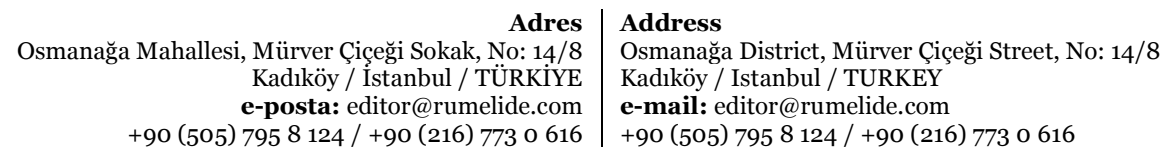


toplumlar bağlamında çeviribilim açısından en azından neyin kaynak neyin erek olduğuna ilişkin karar vermemizi zorlayıcı yeni bir kartografi oluşması nedeniyle güçlükler ortaya çıkmaktadır.

Teknolojik dönemeçten önce, insanların seyahat eylemi için sınırları geçmek zorunda olduğu döneme ait bir inceleme, akla Cronin’in (2008: 270) kültürler arasındaki ilişkilerin ve edebiyatın devam etmesinin yabancı dil öğrenenlerin ve çevirmenlerin çabalarına bağlı olduğunu ifade eden sözünü getirmektedir. İspanyolca öğrenen ve seyahatlerinden aldığı verileri sanatsal üretiminde kullanan Pierre Louÿs'un romanı ve bu romanı dilimize onun farklı dönemlerinde aktarmaya çalışan çevirmenlerimizin ürünleri bu çabalara bir örnektir.

Çalışmamızın araştırma nesnesi üzerinde özellikle odaklandığı dil değiştirimi (code-switching) insanların birbirleriyle iletişim kurarken kullandıkları ve çokdilliliğin hüküm sürdüğü alanlarda sıkça karşımıza çıkan bir strateji olup, özellikle dil öğretimi gibi alanlarda profesyonellerin de çok kullandığı bir yöntemdir. Çokdilli melez metinleri bir göç romanı bağlamında çeviribilim açısından inceleyen yeni bir çalışmada (Ural, 2019) göçmen deneyiminin karmaşık ve egzotik doğasını temsil eden melez bir kaynak metnin çevirisine odaklanılmıştır. Bizim çalışmamıza konu olan romanı ilişkilerin ezen-ezilen, sömüren-sömürülen bağlamlarına oturtamayacağımız açıtır çünkü Fransızca ve İspanyolca dilleri esasen kendine sömürge edinen ulusların dilleridir. İspanya’ya seyahat eden bir Fransız’n yaptığı dil değiştirimi eşitler arasında yapılan bir dil değiştirimidir. Yargılayıcı, tanımlayıcı, hakir görücü bir doğası olmadığı söylenebilir. Öte yandan, romanda o ülkede yaşayan ve azınlık olan insanların kullandığı İspanyolcadan örnekler bulunduğu oranda da ezen-ezilen, sömüren-sömürülen, tanımlayan-tanımlanan ilişkileri kurulabileceği söylenebilir.

\section{Çevirinin kaynak metni olan La Femme et Le Pantin}

Bu incelemeye konu olan çevirilerin kaynak metnini oluşturan romanın yazarı Pierre Louÿs'e 189o'da babasından kalan miras ve özellikle yabancı dil ve müzik sevgisi onu İspanya ve Mağrip ülkelerine taşımıştı (Jiménez, 1997: 39). Yazar La Femme et le Pantin-roman espagnol'un 1898'deki ilk baskısını özellikle kâh romandaki sahneleri kâh İspanya'dan manzaraları gösteren gravürlerle bezenmiş olarak çıkarmıştı. Roman espagnol alt adıyla çıkan romanda bir karnaval zamanı İspanya'da seyahatte olan roman kahramanı Andre Stevenol'un ana dili ve aynı zamanda romanın yazıldığı dil olan Fransızcanın yanı sıra, İspanyolca sözcüklerin bolca kullanımı söz konusudur. Seyahatinde bir İspanyol kızına âşı olan ve onunla bir buluşma ayarlayan Andre, daha buluşamadan genç kızla önceleri bir aşk-nefret ilişkisi yaşamış olan Don Mateo adlı kişiden geçmişte yaşananların hikâyesini dinler. Concepcion Perez adındaki bu genç kız ile Don Mateo'nun yaşadıkları romanın anlatısını oluşturur. İspanyolca bir epigramla başlayan roman içinde, yazar seyahat edilen ülkenin şehir, dağ, nehir, caddelerinin adlarını, dini bayramlarını, o dildeki bağırış çağııışları, hitap şekillerini, para birimlerini, kahramanlara söylettiği şarkı ve türküleri İspanyolca bırakarak ve bunları romanın kurgusuna işleyerek bir İspanya seyahatinde anlatılan bir aşk macerası havasını yaratır. Kısa zamanda popüler olan romanın önce yazarın da yaratımına katıldığı bir piyesi yazılmış, daha sonra çeşitli film uyarlamaları yapılmıştır.

\section{Araştırma nesnesi}

Bu çalışmanın amacı resimli bir seyahat romanının içindeki çokdilli öğelerin çevirisine tarihsel olarak ışık tutup betimlemektir. Çalışmamızın araştırma nesnesini Fransız romancı Pierre Louÿs'un La Femme et le Pantin-roman espagnol (1898) adlı resimli seyahat romanının Osmanlı Türkçesi ve Türkçeye yapılan çevirileri, kısaca Türkçedeki çeviri yolculuğu oluşturmaktadır. Araştırmanın 
bütüncesi Fransızcadan Türkçeye yapılan çeviriler kaynakçasını (bkz. Anamur, 2013: 642) temel almıştır. Kaynak metin 1898 yılında basılmış, gravürlerle resimlenmiş olarak raflarda yerini almıştır, iç kapağında Goya'nın Le Pantin [kukla] adlı heliogravürü ve iç sayfalarında gravür şeklinde resimlendirmeler bulunmaktadır. Birinci çeviri 1922 yılında Hasan Bedreddin tarafından yapılıp Akşam-Teşebbüs Matbaasında basılmış, eser Osmanlı Türkçesine Kadın ve Kukla adıyla çevrilmiştir ve yine resimlidir. Bu çalışma kapsamında anılan çevirinin Türkçeye çeviriyazısı bu makalenin yazarlarından Osman Çeviktay tarafından yapılmıştır. İkinci çeviri 1940 yllında Refi Cevat Ulunay tarafından Türkçeye Kadın ve Oyuncağı adıyla çevrilmiş, Semih Lütfi Kitabevi tarafından basılmıştır ve resimlidir. Üçüncü çeviri 1959 yılında Tahsin Yücel tarafından Kadın ve Kukla adıyla yapılıp, Varlık Yayınları tarafından basılmıştır, resimsizdir. Dördüncü çeviri 1962 yılında Mehmet Doğan Özbay tarafından Kadın ve Kuklası adıyla yapılmış ve Şafak yayınları tarafından basılmıştır, kapak ve arka kapak resimlidir. Kitap cep kitabı formatında olup, çevirinin sonuna belki de forma sayısını tutturabilmek amaçlı olarak 99-138 sayfalar arasına Kadın ve Para adlı bir kısa roman daha eklenmiştir. Bu bölümün açıklaması olarak: "Somerset Maugham’n romanından kısaltılmışı" notu düşülmüştür. Kitabın beşinci ve altıncı çevirileri tekrar Tahsin Yücel tarafından yapılıp sırasıyla 1989 ve 2012 yıllarında, Kadın ve Kukla adıyla Gece Yayınları ve yine Kadın ve Kukla adıyla İmge Yayınevi tarafından basılmıştır ve her ikisi de resimsizdir. Birinci ve ikinci çeviri kaynak metin belirtmemekle beraber 1909 yılı baskısının Velazquez resimlendirmelerini kullanmaktadır. Romanın aynı çevirmene ait farklı yayınevlerinden basılan tarih sırasına göre üçüncü, beşinci ve altıncı çevirileri içinde sadece beşinci çeviri kaynak metin olarak 1898 tarihli ilk baskıyı göstermiştir ve buradaki gravürler kullanılmamıştır. Tarih sırasına göre dördüncü çeviri hangi kaynak metni kullandığını belirtmemiştir; ön ve arka kapakta Brigitte Bardot'nun oynadığı filmi andıran görseller kullanılmıştır.

\section{Çevirmenler ve çevirileri basan yayınevleri hakkında genel bilgi}

\section{EM1'in çevirmeni: Hasan Bedreddin}

Osmanlı çeviri geleneğine ait bir çevirmen olan Hasan Bedreddin (1850-1914) İngilizce, Fransızca ve Almanca dâhil olmak üzere birçok dil biliyordu. Fransızcadan Türkçeye Küçük Kamus-u Fransevi adlı bir sözlük de çıarmış olan çevirmen, Beybaba adıyla biliniyordu. Şemsettin Sami’nin çevirisini yarım bıraktığı Victor Hugo'nun Les Misérables adlı eserini Sefiller adıyla çevirip yayınladı. Kendi adıyla Goethe'den Minyon (1914), Abbé Prévost'tan Manon Lesko (1923), bu makalenin konusunu oluşturan Pierre Louÿs'ten Kadın ve Kukla (1922) çevirilerini yapmıştır. Hasan Merzuk ve Nakş-ı Nur müstear isimleriyle günlük gazetelerde yazmıştır. Hasan Merzuk takma adıyla Cinlerle Muhavere yahud İspirtizm, Fakirizm, Manyetizm adlı bir telif eseri vardır. Kadın ve Kukla çevirisinin basıldığı AkşamTeşebbüs matbaası Dersaadet’te (İstanbul) ciddi eserlerin ve romanların basıldığı bir matbaadır.

\section{EM2'nin çevirmeni: Ref'i Cevat Ulunay}

20. yüzyll yazar ve çevirmenlerinden Refi Cevat Ulunay (1890-1968), İttihat ve Terakki partisine ve Kurtuluş mücadelesine karşıtlığıyla bilinen bir gazeteciydi. 1909'da Galatasaray Lisesi'ni bitirdikten sonra yazarlığa başladı. Alemdar gazetesini çıkardı, siyasi nedenlerden dolayı Sinop, Çorum ve Konya'da sürgün yaşadı (1914-1918).

150likler listesiyle sürgüne gönderilip on beş yıl (1922-1938) yurtdışında yaşadı, 1938 yllında affedilerek Türkiye'ye döndükten sonra, hem Goethe ve Tolstoy gibi merkez edebiyatın önemli yazarlarından, hem de bazı gazeteci ve tiyatro yazarlarının eserlerinden çeviriler yapmıştır. Yeni Sabah

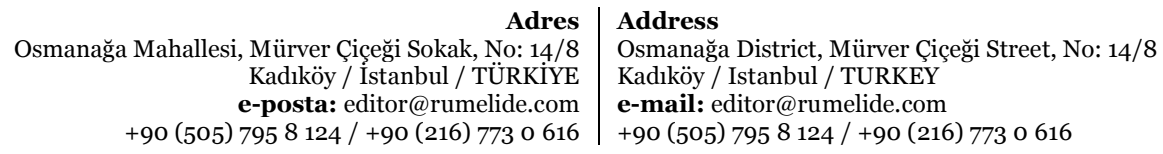


gazetesinde uzun ylllar sürmüş fikra yazarlı̆̆ına 1953’ten ölümüne kadar Milliyet gazetesinde devam etti. Fıkra yazarlığı, tiyatro eleştirmenliği, çeviri kitapları yanı sıra Köle (1945), Enkaz Arasında (1945), Sayıl Firtınalar (2. b. 1958), Dağlar Kiralı (3. b. 1963), Bir Başka Âlem (1964) gibi romanları, İhtişam Diyar Hindistan (1962) adlı bir gezi eseri vardır. Ölümü üzerine Hilmi Yücebaş yazarın hayatı, anıları ve eserleri üzerine Ulunay (1969) başlıklı bir kitap çıkardı (Necatigil, 2002: 379). Kadın ve Oyuncă̆ı adıyla incelediğimiz kitap Semih Lütfi Erciyas - Semih Lütfi Kitabevi tarafından basılmıştır ve karton kapaklı resimli cep kitabı formundadır. Kayserili Ermeni işadamı Semih Lütfi Erciyas'ın İstanbul Sirkeci'de 1906'da kurduğu yayınevi Cumhuriyet döneminin önemli birkaç kitabevi arasındadır.

\section{EM3’ün çevirmeni: Tahsin Yücel}

Nedret Tanyolaç Öztokat yayına hazırladığı Söylem Söylen Yazın başlıklı kitabın sunusunda hocası Tahsin Yücel'i şu sözlerle tanıtmaktadır: "Eğitim, yazın, çeviri, kültür alanlarında sayısız yapıtla genç kuşaklara örnek olmuş bir bilim adamı, yazın insanı, Türkiye’de yapısalcılık ve göstergebilimin tanınmasında bir öncü, engin bilgisini öğrenci ve çalışma arkadaşlarıyla paylaşmış bir hoca, başarılı bir romancı, ödüllere layık görülmüş bir öykücü, çevirmen, sözünü sakınmayan bir eleştirmen. Alçakgönüllü, onurlu, ilkeli ve dürüst bir insan, çalışkan, üretken bir bilim adamı, ülkemizin insanbilimleri alanına önemli katkılarda bulunmuş yetkin bir eleştirmen.” (Tanyolaç-Öztokat 2015: 9). Yücel ortaokul ve liseyi Galatasaray Lisesi'nde okudu (1945-1953). Edebiyat Fakültesi Fransız Dili ve Edebiyatı Bölümü’nü tamamladı (1960). Aynı bölümde asistan oldu, profesörlüğe kadar yükseldi. İlk iki hikâyesi Varlık dergisinin yılbaşlarında yayınladı̆̆ı Yeni Hikâyeler (1950) kitabında çımış, bunu Varlık dergisinde köy ve kasaba notları izlemiştir. Çoğu Fransız edebiyatının belli başlı eserleri olan çeviri kitaplarının sayısı sekseni geçmiştir (Necatigil 2002: 410).

Kendi yazdığı romanların yanı sıra, başta Yapısalcılık, Eleştiri Kuramları, Dil Devrimi ve Sonuçları, Yazın Gene Yazın, Göstergeler, Söylemlerin İçinden olmak üzere, çok sayıda deneme ve araştırma yapıtı vardır. Bıyık Söylencesi, Komşular, Gökdelen ve Vatandaş Fransızcaya çevrilmiştir (TanyolaçÖztokat 2015: 11). Yücel çeviri yapmaya çalışmamızın konusunu oluşturan 1959 tarihli çevirinin de basıldığı Varlık Yayınları'nda 1953 yılında başladı. Kökenini Ankara'da 1993’te kurulan Varlık dergisinin oluşturduğu yayınevi, yayın hayatına İstanbul'da 1946'da önemli çeviriler de basan bir yayınevi olarak devam etmiştir. İlk basılan kitap Cahit Sıtkı Tarancı'nın Otuz Beş Yaş adlı şiir kitabıdır. Ülkemizin önemli yayınevlerinden biridir. 1989 yılında basılan Kadın ve Kukla Ankara'da Gece Yayınları tarafından Gölge Kitapları serisinin 3. kitabı olarak basılmıştır. Tahsin Yücel’in Kadın ve Kukla çevirisi 2012'de ise İmge Kitabevi tarafından yayınlanmıştır. İmge Kitabevi 1987 yılı sonunda siyaset, insan bilimleri, felsefe, tarih, mitoloji, edebiyat ve sanat konularında kitap üretimine başlamıştır.

\section{EM4'ün çevirmeni: M. Doğan Özbay}

M. Doğan Özbay, Fransızca ve İngilizceden çeviriler yapmıştır. Çocuklar için Fransızcadan ve İngilizceden klasikler ve çocuk edebiyatı çevirdiği gibi, Altın Kitaplar'dan macera romanları da çevirmiştir. İyi Gün Yayınları ile Jules Verne'den Denizler Altında 20,ooo Fersah (1957), Robensonlar Mektebi, Daniel Defoe'dan Robenson Crusoe (1965); Başkan Yayınları ile Paul Jacques Bonzon'dan Kırmızı Gül (1972) ve Gece Gelen Ziyaretçi (1973) adlı çeviri kitapları bulunmaktadır (Öncü, 2017). Çalışmamıza konu olan Kadın ve Kuklası adlı çevirisi 1962'de İstanbul'da Şafak Yayınları tarafından 
Turkish translations of multilingualism in the context of illustrated travel literature: La Femme et Le Pantin, roman espagnol / A. Özkan; O. Çeviktay (pp. 471-489)

basılmıştır. Kapak içinde "Şafak yayınları Gazeteci-Kitap ve Yayınevinin bir neşriyat koludur" bilgisi bulunmaktadır.

\section{Kuramsal çerçeve ve yöntem}

Antoine Berman "La Traduction et ses discours" ["Çeviri ve Çeviri Üstüne Söylemler" (çev. Rifat. 2004)] başlıklı makalesinde çeviribilimin görevlerinden birinin "çevirmen üzerine bir düşünce geliştirmek" olduğunu söyler çünkü "çevirmen, çeviri üstüne söylemlerde en çok unutulmuş olandır" (age, 26). Bununla birlikte, çeviribilimde vurgunun kaynaktan, özgün metinden çeviriye kaydırıldı̆̆ı, çevirmenin gözle görülür duruma geldiği kuram odaklı söylemler ışı̆̆ında çevirmenler ve çeviri kararları incelenebilir. Lawrence Venuti, Antoine Berman'ın çeviriyi, metinsel yorumlama nesnesi ve kişilerarası iletişimin bir aracı, bir başka deyişle "öznelerarası karşılaşmanın bir yöntemi” olarak tanımladığını belirtir (Venuti 2008: 84). Ayrıca, Venuti, Friedrich Schleiermacher'ın öne sürdüğü iki yöntemden bahseder; ya çevirmen yazarı olabildiğince rahat bırakır ve okuru yazara yaklaştırır ya da okuru olabildiğince rahat bırakır ve yazarı okura yaklaştırır. Schleiermacher birinci yöntemden yanaydı. Çeviri okurunu yurtdışı seyahatine çıkarmayı tercih ediyordu (Krş. Venuti 2008: 84 ). Schleiermacher'dan yola çıkan Lawrence Venuti erek metin okuyucusuna özgün bir yapıt okuyormuş hissi vermeyi sağlayan çeviri stratejilerini yerlileştirme (domestication), kaynak metnin erek kültür ve dile yabancı bazı ögelerini saklamayı sağlayan çeviri stratejilerini ise yabancılaştırma (foreignization) şeklinde nitelendirmiştir. Bir seyahat romanındaki dil değiştirimi çevirilerinin incelenmesini içeren bu çalışma, çevirmenlerin kullandığı stratejilerin yerlileştirme ya da yabancılaştırma kutuplarına doğru hareketlerini ele almaktadır.

Erek kültürün gerçeği olan çeviri, araştırmayı yapılmış çeviri üzerinde başlatmayı gerektirdiğinden betimleyici çalışmamızda Gideon Toury'nin çeviri normlarını inceleme yöntemi olarak ortaya koyuyoruz zira Toury'nin (1995) ifade ettiği gibi çeviri eylemini normlar yönetir. Normlar ise dolaysız olarak gözlenemediğinden metinlerden ve metin-dışı kaynaklardan oluşturulmak zorundadır. Şu halde yöntem olarak ise bu çalışmada Toury'nin çeviri normları kullanılacaktır.

\section{Çeviri metinlerin incelenmesi}

Yapılan çeviri incelemeleri İspanyolca dil değiştirimi gözlemlenen yerlere odaklanmıştır. Bulguların listelenmesi ve tartışılmasında Pierre Louÿs'un La femme et le pantin, roman espagnol adlı eseri, KM (kaynak metin) olarak anılmıştır. Erek metinlere gelince; 1922 tarihli Kadın ve Kukla adlı Hasan Bedreddin çevirisi EM1 olarak; 1940 tarihli Kadın ve Oyuncağı adlı Ref'i Cevat Ulunay çevirisi EM2 olarak ve inceleme kolaylığı açısından 1959/1989/2012 tarihli Kadın ve Kukla adlı Tahsin Yücel çevirileri EM3 olarak; 1962 tarihli Kadın ve Kuklası adlı M. Doğan Özbay çevirisi ise EM4 olarak anılmıştır. Çokdillilik görülen yerler temalarına göre gruplandırılmış ve ortaya epigramlar, dini bayramlar, şehir, dağ, nehir, cadde adlarının oluşturduğu yer isimleri, bağırış çağırışlar, hitap şekilleri, para birimleri, kahramanların söylediği şarkı ve türkülerden oluşan 6 tema çımıştır. Bunun yanı sıra dipnotlar ve çevirmen notları şeklinde 2 alt kategori daha oluşturulmuştur.

\section{Epigramların çevrilmesi}

Romandaki epigramlar çevirmenler tarafından aşağıda Tablo 1.'de gösterildiği şekilde çevrilmiştir.

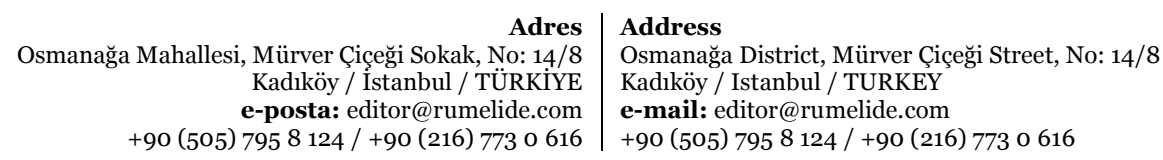




\begin{tabular}{|c|c|c|c|c|}
\hline KM (1898) & EM1 (1922) & EM2 (1940) & $\begin{array}{l}\text { EM3 } \\
(1959 / 1989 / 2012)\end{array}$ & EM4 (1962) \\
\hline $\begin{array}{l}\text { Siempre me V. diciendo } \\
\text { Que se muere V. por mi: } \\
\text { Muerase V. y lo veremos } \\
\text { Y despues dire que si. } \\
\text { (s.1) }\end{array}$ & $\begin{array}{l}\text { Her zaman sen bana } \\
\text { diyorsun ki: } \\
\text { "Ölürüm, ben sana } \\
\text { feda olurum!” } \\
\text { Öl de âlemde bari } \\
\text { bir görelim... } \\
\text { Sözünü doğru ol } \\
\text { zaman bulurum. (s. } \\
\text { 3) }\end{array}$ & $\begin{array}{l}\text { Metinde yer } \\
\text { almamakta- } \\
\text { dır. }\end{array}$ & $\begin{array}{l}\text { (1959) Metinde yer } \\
\text { almamaktadir. } \\
\text { Siempre me V. diciendo } \\
\text { Que se muere V. por mi: } \\
\text { Muerase V. y lo veremos } \\
\text { Y despues dire que si. } \\
\text { 1989- (s. 9) 2012- (s. 7) }\end{array}$ & $\begin{array}{l}\text { Metinde yer } \\
\text { almamakta- } \\
\text { dir. }\end{array}$ \\
\hline
\end{tabular}

Tablo 1. Epigramların çevrilmesi

Seyahat romanının başında bunun bir İspanyol romanı olduğunu anlatan alt başlı̆̆ın yanı sıra, okurun İspanyolca bilmesi halinde romanın konusunun da anlaşılmasını sağlayan bir epigram bulunmaktadır. Bu epigram romanın bir özeti gibidir (Jiménez, 1997: 46). KM'de İspanyolca olan bu metin EM1'de Türkçeye çevrilmiştir. EM2 ve EM4'de epigram yok sayılmıştır. EM3’te ise, 1959 yllında yok sayılmış, 1989 ve 2012'de İspanyolca olarak çevirinin başına konmuştur.

\section{Dini öğeler içeren ifadelerin çevrilmesi}

Dini öğeler içeren ifadeler çevirmenler tarafından aşağıda Tablo 2.'de verildiği gibi çevrilmiştir.

\begin{tabular}{|c|c|c|c|c|}
\hline KM (1898) & EM1 (1922) & EM2 (1940) & $\begin{array}{l}\text { EM3 } \\
(1959 / 1989 / \\
\text { 2012) }\end{array}$ & EM4 (1962) \\
\hline $\begin{array}{l}\text { Le carnaval } \\
\text { d'Espagne ne se } \\
\text { termine pas, } \\
\text { comme le nôtre, à } \\
\text { huit heures du } \\
\text { matin le } \\
\text { mercredi des } \\
\text { Cendres. Sur la } \\
\text { gaieté } \\
\text { merveilleuse de } \\
\text { Séville, le } \\
\text { memento quia } \\
\text { pulvis es ne } \\
\text { répand que pour } \\
\text { quatre jours son } \\
\text { odeur de } \\
\text { sépulture: et le } \\
\text { premier } \\
\text { dimanche de } \\
\text { carême, tout le } \\
\text { carnaval } \\
\text { ressuscite. C'est } \\
\text { le Domingo de } \\
\text { Piñatas, le } \\
\text { dimanche des } \\
\text { Marmites, la } \\
\text { Grande Fête. } \\
\text { s.4 }\end{array}$ & 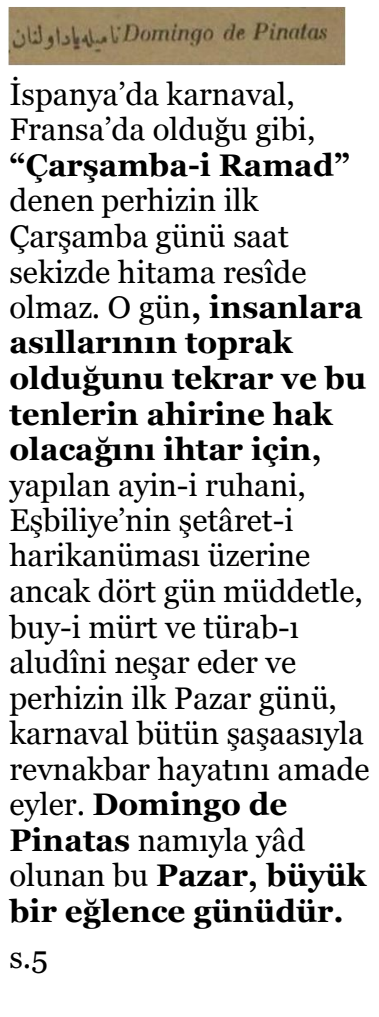 & $\begin{array}{l}\text { İspanya'daki } \\
\text { "karnaval” } \\
\text { Fransa'daki gibi } \\
\text { (küller } \\
\text { çarşambası) } \\
\text { denilen günde, } \\
\text { sabahın sekizinde } \\
\text { nihayet bulmaz. } \\
\text { Sevil şehrinin } \\
\text { coşkun neşvesinin } \\
\text { üzerine matem } \\
\text { rüzgarları ancak } \\
\text { dört gün için ölüm } \\
\text { kokularını yayabilir. } \\
\text { Perhizin birinci } \\
\text { Pazar günü karnaval } \\
\text { yeniden dirilir. } \\
\text { Domingo de } \\
\text { Pinatas } \\
\text { (tencerelerin } \\
\text { pazar günü) tabir } \\
\text { edilen gün büyük } \\
\text { bir bayramdır. }\end{array}$ & $\begin{array}{l}\text { İspanya } \\
\text { karnavalı } \\
\text { bizdeki gibi } \\
\text { ölüler } \\
\text { çarşambası } \\
\text { sabahının } \\
\text { sekizinde } \\
\text { bitmez. } \\
\text { Memento } \\
\text { quia pulvis } \\
\text { es, Sevilla'nın } \\
\text { o eşsiz neşesi } \\
\text { üzerine ancak } \\
\text { dört gün yayar } \\
\text { o mezarlık } \\
\text { kokusunu: ve } \\
\text { büyük perhizin } \\
\text { ilk pazarında } \\
\text { bütün karnaval } \\
\text { yeniden } \\
\text { canlanır. } \\
\text { Domingo de } \\
\text { Pinatas'tır. } \\
\text { Tencereler } \\
\text { Pazarıdır. } \\
\text { Büyük } \\
\text { Bayramdır bu. } \\
\text { s.3/11/11 }\end{array}$ & $\begin{array}{l}\text { İspanya karnavalı, } \\
\text { bizimki gibi, } \\
\text { büyük perhizin } \\
\text { ilk çarşamba } \\
\text { günü, saat sekizde } \\
\text { sona ermez. Sevilla } \\
\text { şehrine çöken } \\
\text { sessizlik ancak dört } \\
\text { gün devam eder. } \\
\text { Büyük perhizin ilk } \\
\text { pazar günü ise } \\
\text { karnaval tekrar } \\
\text { canlanır. Bu, bir } \\
\text { mahrumiyet } \\
\text { devresini takip } \\
\text { eden, bir } \\
\text { cosskunluk } \\
\text { panayırı, bir } \\
\text { Büyük } \\
\text { Bayram'dır. } \\
\text { s.6 }\end{array}$ \\
\hline
\end{tabular}




\begin{tabular}{|c|c|c|c|c|}
\hline $\begin{array}{l}\text { Or, le } 23 \text { février } \\
\text { 1896, } \\
\text { Dimanche de } \\
\text { Piňatas André } \\
\text { Stévenol voyait } \\
\text { approcher la fin } \\
\text { du carnaval de } \\
\text { Séville avec un } \\
\text { léger sentiment } \\
\text { de dépit, ... } \\
\text { s.-4, } 5\end{array}$ & 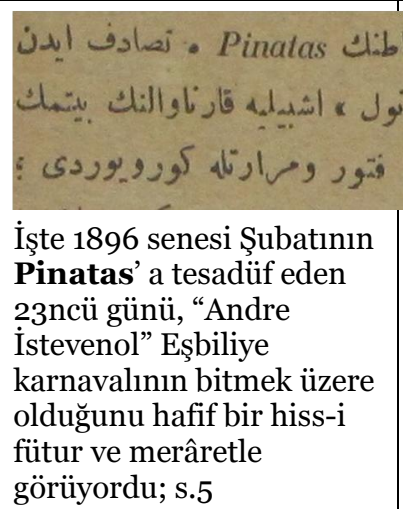 & $\begin{array}{l}1896 \text { senesi } \\
\text { şubatının yirmi } \\
\text { üçüncü günü } \\
\text { Andre Stevenol } \\
\text { Sevil karnavalının } \\
\text { bìtmeğe } \\
\text { yaklaşmasını, } \\
\text { arzusu yerine } \\
\text { gelmemiş bir adam } \\
\text { hissi ile } \\
\text { seyrediyordu. }\end{array}$ & $\begin{array}{l}23 \text { Şubat 1806, } \\
\text { Pinatas } \\
\text { Pazarı günü, } \\
\text { André } \\
\text { Stévenol, } \\
\text { Sevilla } \\
\text { karnavalının } \\
\text { bitmek üzere } \\
\text { olduğunu hafif } \\
\text { bir küskünlük } \\
\text { duygusuyla } \\
\text { görüyordu,... }\end{array}$ & $\begin{array}{l}\text { İşte, } 23 \text { Şubat } \\
\text { 1896'da, Büyük } \\
\text { Perhizi takip } \\
\text { eden ilk Pazar } \\
\text { günü, André } \\
\text { Stevenol karnavalın } \\
\text { sona ermek üzere } \\
\text { olduğunu üzülerek } \\
\text { düşünüyordu. }\end{array}$ \\
\hline
\end{tabular}

Tablo 2. Dini öğeler içeren ifadelerin çevrilmesi

İspanya'da kutlanan bir dini bayramın Fransa'da kutlanandan farkının tanıtıldığı ilk örnekte EM1 ve EM2'de “comme le nôtre" ifadesi Türkçeye "Fransa'daki gibi, Fransa'da olduğu gibi” şeklinde aktarlırken, EM3 ve EM4'te "bizdeki gibi” şeklinde çevrilmiştir. Böylece metni anlatıcı ve/veya seyyahın gözünden okumayı mümkün kıldıkları söylenebilir. Latince çokdillilik örneği olan Memento quia pulvis es [Toz olduğunu unutma] ifadesinin çevirisine gelince; EMı'de sözün açıklaması Latince sözün geri kalan kısmını da (...et in pulverem reverteris) [insanlara asıllarının toprak olduğunu tekrar ve bu tenlerin ahirine hak olacağını ihtar için] içerecek şekilde tamamen Türkçeye çevrilmiştir. Çevirmenin erek okuyucunun kültür dizgesine uygun gelecek bir strateji uyguladığı söylenebilir. EM2 ve EM4'te Latince söz [matem havası] ve [sessizlik] şeklinde çevrilerek ifade edilmiştir. EM3’te ise bu Latince söz olduğu gibi bırakılarak yabancı havanın sürdürüldüğü söylenebilir. İspanyolca Domingo de Piñatas ifadesinin çevirisinde ise; EM1'de bu ifade Osmanlı Türkçesi metnin içinde Latin harfleriyle bırakılmıştır ve yabancı havayı bu şekilde koruduğu söylenebilir. EM2'de ifade aynen bırakılmış ve yanına parantez içinde kaynak metindeki açılama verilmiştir. EM3’te çevirmen ifadeyi aynen bırakmış ve hiçbir açıklama yapmamıştır, zira kendisinden sonra gelen "Tencereler Pazarı" ve "Büyük Bayram" ifadelerinin açıklayıcı olduğunu düşündüğü söylenebilir. EM4’te "Domingo de Piñatas" ifadesi eksiltilerek açıklayıcı çeviri yapılmıştır.

Yukarıda ikinci sırada listelenen ve dil değiştiriminin gözlemlendiği Dimanche de Piñatas ifadesinin çevirisinde; EM1'de çevirmen "Piñatas” ifadesini yine Latin harfleriyle bırakmış, Fransızca kısmını ise çevirmiştir. EM2'de dil değiştirimi olan bu ifade eksiltilmiş, EM3’te "Pinatas Pazarı günü” şeklinde çevrilerek yabancı hava korunmuştur. EM4’te ise çevirmen "Büyük Perhizi takip eden ilk Pazar" diyerek açıklayıcı çeviri yapmıştır.

\section{Yer adlarının çevrilmesi}

Romandaki yer adlarını çevirmenler aşağıdaki Tablo 3.'te gösterildiği gibi çevirmişlerdir.

\begin{tabular}{|l|l|l|l|l|}
\hline KM (1898) & EM1 (1922) & EM2 (1940) & $\begin{array}{l}\text { EM3 } \\
\text { (1959/1989/2012) }\end{array}$ & EM4 (1962) \\
\hline $\begin{array}{l}\text { Il quitta las Sierpes. } \\
\text { (s.5) }\end{array}$ & $\begin{array}{l}\text { "Sierpes"ten } \\
\text { mufarakat etti. (s.6) }\end{array}$ & $\begin{array}{l}\text { Sierpes'den } \\
\text { uzaklaştı. (s.6) }\end{array}$ & $\begin{array}{l}\text { Las Sierpes'ten } \\
\text { ayrıld. } \\
\text { (s.4/12/12) }\end{array}$ & $\begin{array}{l}\text { Sierpes'den } \\
\text { ayrild. (s.6) }\end{array}$ \\
\hline $\begin{array}{l}\text {...passa entre la } \\
\text { Giralda et l'antique } \\
\text { Alcazar, et... (s.5) }\end{array}$ & $\begin{array}{l}\text { "Ciralda" ile eski "El- } \\
\text { Kasr"dan geçti ve... } \\
\text { (s.6) }\end{array}$ & $\begin{array}{l}\text { Giralda ile eski } \\
\text { Alkazar'ın } \\
\text { arasından...( } \\
\text { s.6) }\end{array}$ & $\begin{array}{l}\text { Giralda ile eski } \\
\text { Alkazar arasından } \\
\text { geçti ve... } \\
\text { (s.4/12/12) }\end{array}$ & $\begin{array}{l}\text { Giralda'yla } \\
\text { eskicazar'dan } \\
\text { (s.6) }\end{array}$ \\
\hline
\end{tabular}




\begin{tabular}{|c|c|c|c|c|}
\hline $\begin{array}{l}\text {...par la calle } \\
\text { Rodrigo il gagna... } \\
\text { (s.5) }\end{array}$ & $\begin{array}{l}\text { Rodrigo } \\
\text { sokağından...(s.6) }\end{array}$ & $\begin{array}{l}\text { Rodrigo } \\
\text { caddesini takip } \\
\text { ederek... (s.6) }\end{array}$ & $\begin{array}{l}\text { calle } \\
\text { Rodrigo'dan... (s.4) } \\
\text { calle Rodrigo } \\
\text { yoluyla...(s.12/12) }\end{array}$ & $\begin{array}{l}\text { Rodrigo } \\
\text { caddesinden } \\
\text { (s.6) }\end{array}$ \\
\hline $\begin{array}{l}\text {...il gagna les } \\
\text { Delicias, (s.5) }\end{array}$ & $\begin{array}{l}\text {...Delisiyas mesiresine } \\
\text { geldi. (s.6) }\end{array}$ & $\begin{array}{l}\text { Delicias'ın } \\
\text { gölgeli } \\
\text { ağaçlarının } \\
\text { yanından... (s.6) }\end{array}$ & $\begin{array}{l}\text { Delicias'a... gitti. } \\
(\mathrm{s} .4 / 12 / 13)\end{array}$ & $\begin{array}{l}\text { Delicias'da } \\
\text { durdu. (s.6) }\end{array}$ \\
\hline $\begin{array}{l}\text {...Champs-Elysees } \\
\text { d'arbres... (s.5) }\end{array}$ & $\begin{array}{l}\text {...bir "Şanzelize"ye } \\
\text { benzeyen... (s.6) } 6\end{array}$ & $\begin{array}{l}\text { Metinde yer } \\
\text { almamaktadır } \\
\text {. }\end{array}$ & $\begin{array}{l}\text { Ağaçların Champs- } \\
\text { Elysees'ine... } \\
\text { (s.4/12/13) }\end{array}$ & $\begin{array}{l}\text { Ağaçlariyla } \\
\text { Champs- } \\
\text { Elysées'den } \\
\text { farksiz olan... } \\
\text { (s.6) }\end{array}$ \\
\hline $\begin{array}{l}\text {...le longue de } \\
\text { l’immense } \\
\text { Guadalquivir } \\
\text { peuple de vaisseaux. } \\
\text { (s.5) }\end{array}$ & $\begin{array}{l}\text {...gemilerle dolu Vadi } \\
\text { el-Kebir nehri } \\
\text { boyunca... (s.6) } 6\end{array}$ & $\begin{array}{l}\text {...gemilerle dolu } \\
\text { olan geniş } \\
\text { Guadalakivir' } \\
\text { e vasil oldu. } \\
\text { (s.6) }\end{array}$ & $\begin{array}{l}\text {...kayıklarla dolu } \\
\text { uçsuz bucaksız } \\
\text { Guadalquivir } \\
\text { boyunca... } \\
\text { (s. } 4 / 12 / 13)\end{array}$ & $\begin{array}{l}\text {...gemilerle } \\
\text { dolu } \\
\text { Guadalquivi } \\
\text { r'in } \\
\text { kiyısında... } \\
\text { (s.6) }\end{array}$ \\
\hline À Sevillle... (s.5) & Eşbiliye'de... (s.6) & Sevil'de, (s.6) & $\begin{array}{l}\text { Sevilla'nın } \\
\text { (s.4/12/13) }\end{array}$ & $\begin{array}{l}\text { Sevilla'da } \\
\text { (s.6) }\end{array}$ \\
\hline $\begin{array}{l}\text {...dans Cordoue, } \\
\text { dans Jérez, ou dans } \\
\text { Malaga? (s.7) }\end{array}$ & $\begin{array}{l}\text { Kurtuba'da mı, } \\
\text { "Yerez"de mi, yahut } \\
\text { "Malaga"da mı? (s.12) }\end{array}$ & $\begin{array}{l}\text {...onu } \\
\text { Korku'da, } \\
\text { Jerez'de yahut } \\
\text { Malaga'da } \\
\text { aramak lazımdı. } \\
\text { (s.11) }\end{array}$ & $\begin{array}{l}\text { Cordoue'da mı, } \\
\text { Jérez de mi, Malaga } \\
\text { da mı? } \\
1959 \text { (s.8) } \\
\text { Cordoba da mı, } \\
\text { Jérez de mi, Malaga } \\
\text { da mı? } \\
(\mathrm{s} .16 / 16)\end{array}$ & $\begin{array}{l}\text { İspanya'nın } \\
\text { bütün } \\
\text { şehirlerini } \\
\text { dolaşamazdı } \\
\text { ya... (s.9) }\end{array}$ \\
\hline
\end{tabular}

Tablo 3. Yer adlarının çevrilmesi

Seyahat romanındaki gerçek yer isimlerinin çevrilmesi özellikle önemlidir. EM1'de Endülüs’te bulunan bu yer isimleri Osmanlı Türkçesinde söylendiği biçimde yazılmıştır: Séville için Eşbiliye, Guadalquivir için Vadi-el-Kebir, Cordoue için Kurtuba. Fransızca Champs-Elysees için Şanzelize karşılığını kullanılmıştır. Ayrıca calle Rodrigo gibi cadde isimlerindeki İspanyolca "calle" sözcüğü de Türkçeye çevrilmiştir. EM2'de tüm yer isimleri Türkçe okunduğu gibi yazılmıştır: Séville için Sevil, Guadalquivir için Guadalkivir, Cordoue için Korku karşllıları tercih edilmiştir. Yine EM2'de Fransızca Champs-Elysees tamlaması eksiltilmiş, calle Rodrigo gibi cadde isimlerindeki İspanyolca "calle" sözcüğü de Türkçeye çevrilmiştir. EM3’te çevirmen tüm yer isimlerini İspanyolca yazıldığı gibi bırakmıştır. Çevirmen ilk çevirisinde Fransızca Cordoue şeklinde bıraktığı yer ismini 1989 ve 2012 yılı çevirilerinde İspanyolca Cordoba şeklinde düzeltmiştir. Fransızca Champs-Elysees sözcügünü ise yazıldığı gibi bırakmıştır. Calle sözcüğünü aynen bırakarak İspanyol havasını koruduğu söylenebilir. EM4’te yer isimlerinin tümü İspanyolca yazıldığı gibi bırakılmıştır. Ancak "calle” sözcüğüne [cadde] karşllı̆̆ı verilmiştir. Ne var ki, tablodaki son örnekte görüldüğü gibi, bu çeviride KM’deki şehir isimleri [İspanya’nın bütün şehirlerini] şeklinde çevrilerek hem genelleme hem de eksiltme yapılmıştır.

\section{Bağırış, çağırış ve konuşmaların çevrilmesi}

Romanda geçen bağırış, çağırış ve konuşmalar çevirmenlerce aşağıda Tablo 4’te verildiği gibi çevrilmiştir. 
Turkish translations of multilingualism in the context of illustrated travel literature: La Femme et Le Pantin, roman espagnol / A. Özkan; O. Çeviktay (pp. 471-489)

\begin{tabular}{|c|c|c|c|c|}
\hline KM (1898) & EM1 (1922) & EM2 (1940) & $\begin{array}{l}\text { EM3 } \\
(1959 / 1989 / 2012)\end{array}$ & EM4 (1962) \\
\hline $\begin{array}{l}\text { "i Anda! i Hombre! } \\
\text { que no me conoce !" } \\
\text { (s.4) }\end{array}$ & $\begin{array}{l}\text { "Haydi! Savul! Ey } \\
\text { beni tanımayan } \\
\text { insan!" (s.4) }\end{array}$ & $\begin{array}{l}\text { Anda! Hombre! que } \\
\text { ne me conoce! (s.5) }\end{array}$ & $\begin{array}{l}\text { “i Anda ! i Hombre ! } \\
\text { que no me conoce !” } \\
\text { (s.3/11/11) }\end{array}$ & $\begin{array}{l}\text { BENI TANIYAN } \\
\text { VAR MI? (s.5) }\end{array}$ \\
\hline $\begin{array}{l}\text { Le cri des enfants } \\
\text { vendeurs dominait } \\
\text { tout : « i Huevo'! } \\
\text { Huevo'! » C'était } \\
\text { la bataille des œufs. } \\
\text { « i Huevo'! ‘ } \\
\text { Quien quiere } \\
\text { huevo'? ! A do' } \\
\text { perra' gorda' la } \\
\text { docena ! » } \\
\text { (s.5) }\end{array}$ & $\begin{array}{l}\text { Yumurta satan } \\
\text { çocukların nidaları } \\
\text { her şeye hâkim } \\
\text { oluyor, } \\
\text { "Yumurta! } \\
\text { Yumurta! Hani } \\
\text { ya! Yumurta } \\
\text { isteyen, düzinesi } \\
\text { riyale!" } \\
\text { âvâzesi her taraftan } \\
\text { işitiliyordu. } \\
\text { Yumurta } \\
\text { muharebesi zamanı } \\
\text { idi. } \\
\text { (s.6-7) }\end{array}$ & $\begin{array}{l}\text { Gürültünün üzerine } \\
\text { çocukların sesleri } \\
\text { işitiliyordu: } \\
\text { - Huevo! Huevo... } \\
\text { Yumurta } \\
\text { muharebesi! } \\
\text { Huevo! Quieu } \\
\text { quiero Huevo, a } \\
\text { do perra gorda la } \\
\text { docena! } \\
\text { (s. 6-7) } \\
\text { (İspanyolca } \\
\text { deyişteki imla } \\
\text { hataları özgün } \\
\text { metne aittir) }\end{array}$ & $\begin{array}{l}\text { Satıcı çocukların } \\
\text { bağırtıları her şeyi } \\
\text { bastırıyordu: } \\
\text { “Huevo! Huevo!” } \\
\text { Yumurta savaşı vardı. } \\
\text { “ Huevo' ! Quien } \\
\text { quiere huevo'? A } \\
\text { do' perra' gorda' la } \\
\text { docena!” } \\
\text { (s.5/13/13) }\end{array}$ & $\begin{array}{l}\text { Satıcı çocukların } \\
\text { bağırmaları } \\
\text { bütün } \\
\text { gürültüleri } \\
\text { bastırır gibiydi: } \\
\text { «Huevo! } \\
\text { Huevo! = } \\
\text { Yumurta! } \\
\text { Yumurta! » } \\
\text { Bu yaygaracı } \\
\text { çocuklar } \\
\text { başlayan } \\
\text { yumurta } \\
\text { muharebesinin } \\
\text { cephesini } \\
\text { satıyorlardı. } \\
\text { (s.6) }\end{array}$ \\
\hline $\begin{array}{l}\text {...avec un «" } \\
\text { Muchīsima' grasia', } \\
\text { cavayero », jargonné } \\
\text { à l'andalouse. } \\
\text { (s.5) }\end{array}$ & $\begin{array}{l}\text { Endülüslülere } \\
\text { mahsus şive ile } \\
\text { birkaç kelime-i iltifat } \\
\text { bezletmişti. } \\
\text { (s.5) }\end{array}$ & $\begin{array}{l}\text { Endülüs şivesi bir } \\
\text { cümle } \\
\text { mırıldandılktan } \\
\text { sonra... (s.6) }\end{array}$ & $\begin{array}{l}\text { Endülüsce bir } \\
\text { «Muchisima' grasia', } \\
\text { cavayero », dedikten } \\
\text { sonra... (1959, s.4) } \\
\text { Endülüsce ağziyla } \\
\text { "Muchisima' grasia' } \\
\text { cavayero," diyerek... } \\
\text { (1989, s.12) } \\
\text { Endülüslü ağziyla } \\
\text { "Muchisima' grasia, } \\
\text { cavayero" diyerek... } \\
\text { (2012, s.12) }\end{array}$ & $\begin{array}{l}\text { Metinde yer } \\
\text { almamaktadır. }\end{array}$ \\
\hline
\end{tabular}

Tablo 4. Bağırış, çağırış ve konuşmaların çevirisi

Kaynak metnin içinde romanın İspanya'da geçtiğini hatırlatan birçok bağırış, çağırış ve haykırış da İspanyolca yazılmıştır. İlk örnekteki “i Anda ! i Hombre ! que no me conoce !” ifadesi EM1 ve EM4’te Türkçeye çevrilmiştir. EM2 ve EM3’te ise aynen bırakılmıştır. İkinci örnekte bulunan [ « i Huevo’ ! Huevo' ! » C'était la bataille des oufs. " i Huevo' ! ¿ Quien quiere huevo' ? ! A do' perra' gorda' la docena ! »] ifadesindeki İspanyolca haykırışlar EM1'de Türkçeye çevrilmiştir. EM2 ve EM3’te bu ifadeler İspanyolca bırakılıp çevrilmezken, EM4’te çevirmen sadece Huevo sözcüğünün yumurta olduğunu belirtecek şeklinde yanına = (eşittir) işareti koymuş ve diğer İspanyolca haykırışları eksilterek aktarmıştır. Ayrıca, tabloda gösterildiği gibi, EM4’te çevirmen çocukların oyun yumurtalarını belki de cephaneye benzetip ekleme yapmıştır ama basım hatası olduğunu düşündürtecek şekilde bu ekleme çeviride [cephesini] şeklinde yer almaktadır.

Tabloda ikinci surada verilen « Muchīsima' grasia', cavayero » şeklindeki Endülüs şivesiyle konuşulan ifadelerin çevirisine bakıldığında, EMı'de bu ifadeler bir iltifat olarak yorumlanarak [Endülüslülere mahsus şive ile birkaç kelime-i iltifat bezletmişti] şeklinde; EM2'de konuşma ifadeleri eksiltilerek [Endülüs şivesi bir cümle mırıldandıktan sonra...] şeklinde çevrilmiştir. EM4'te bu ifadeler tamamen eksiltilirken, EM3’te bu konuşma ifadeleri aynen bırakılmıştır.

\begin{tabular}{|c|c|}
\hline 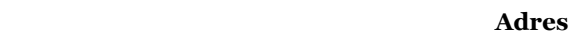 & Address \\
\hline Osmanağa Mahallesi, Mürver Çiçeği Sokak, No: 14/8 & Osmanağa District, Mürver Çiçeği Street, No: 14/8 \\
\hline Kadıköy / İstanbul / TÜRKIYE & Kadıköy / Istanbul / TURKEY \\
\hline e-posta: editor@rumelide.com & e-mail: editor@rumelide.com \\
\hline +90 (505) 7958124 / +90 (216) 773 o 616 & +90 (505) $7958124 /$ +90 (216) 7730616 \\
\hline
\end{tabular}




\section{Hitap biçimleri}

Romanda geçen İspanyolca hitap biçimleri çevirmenlerce aşağıda Tablo 5.'teki gibi çevrilmiştir.

\begin{tabular}{|c|c|c|c|c|}
\hline KM (1898) & EM1 (1922) & EM2 (1940) & $\begin{array}{l}\text { EM3 } \\
(1959 / 1989 / 2012)\end{array}$ & EM4 (1962) \\
\hline $\begin{array}{l}\text { les caballeros et } \\
\text { les seňoras (s.6) }\end{array}$ & $\begin{array}{l}\text { kadın ve } \\
\text { erkeklere (s.7) }\end{array}$ & $\begin{array}{l}\text { caballero ve } \\
\text { senoralar ( } \mathrm{s} .7)\end{array}$ & $\begin{array}{l}\text { caballerolar, } \\
\text { senoralar da } \\
(\mathrm{s} .5 / 13 / 13)\end{array}$ & $\begin{array}{l}\text { kadin ve } \\
\text { erkekler (s.6) }\end{array}$ \\
\hline $\begin{array}{l}\text { Au moins je n'en } \\
\text { dirai pas de mal, je } \\
\text { ne médirai pas, } \\
\text { cabeyro! (s.10) }\end{array}$ & $\begin{array}{l}\text { Metinde yer } \\
\text { almamaktadır. } \\
\text { Hiç olmazsa } \\
\text { hakkında fena } \\
\text { söylemeyeceğim, } \\
\text { zemm-ü giybet } \\
\text { etmeyeceğim! (s.18) }\end{array}$ & $\begin{array}{l}\text { Onu zem edemem } \\
\text { Kaballero! Fakat } \\
\text { mademki o kadar } \\
\text { merak } \\
\text { ediyorsunuz... } \\
\text { (s.14) }\end{array}$ & $\begin{array}{l}\text {.. aleyhinde } \\
\text { konuşmıyacağım } \\
\text { onun, cabeyro! } \\
\text { (1959, s.12) } \\
\text {... hakkında kötü } \\
\text { konuşmayacağım } \\
\text { onun, cabeyro! } \\
\text { (s.21/s.21) }\end{array}$ & $\begin{array}{l}\text { Metinde yer } \\
\text { almamaktadır. } \\
\text { Mamafih, benden } \\
\text { fena bir şey de } \\
\text { istemiyorsunuz. } \\
\text { (s.11) }\end{array}$ \\
\hline $\begin{array}{l}\text { Ce n'est pas la } \\
\text { chambre qu'il faut à } \\
\text { une mozita. (s.49) }\end{array}$ & $\begin{array}{l}\text { Bu kıza böyle oda } \\
\text { yakışmaz. (s.92-93) }\end{array}$ & $\begin{array}{l}\text { Benim gibi bir } \\
\text { kızoğlankıza } \\
\text { böyle bir yatak } \\
\text { yakışmaz. (s.62) }\end{array}$ & $\begin{array}{l}\text { Bir mozita'ya göre } \\
\text { bir oda değil burası. } \\
\text { (s.61/69/73) }\end{array}$ & $\begin{array}{l}\text { Burası bir } \\
\text { bâkireye lâyıı } \\
\text { bir oda değil! } \\
\text { (s.58) }\end{array}$ \\
\hline
\end{tabular}

Tablo 5. Hitap biçimlerinin çevrilmesi

Dil değiştirimi içeren hitap biçimlerinin çevirisinde ilk sırada verilen örnekte EM1 ve EM4’te çevirmenler "les caballeros et les seňoras" şeklindeki İspanyolca hitapları ortadan kaldırarak [kadınlar ve erkekler] şeklinde Türkçeye çevirmiştir. Buna karşllık, EM2 ve EM3’te [caballerolar ve senoralar...] şeklinde ifade edilmiştir. İkinci sıradaki örnekte “cabeyro!” ifadesi EM1 ve EM4’te eksiltilmiştir. EM2'de [kaballero] şeklinde farklı yazılarak aktarılırken, EM3’te olduğu gibi bırakılmıştır. Son sıradaki örnekte ise "mozita" ifadesi EM1, EM2 ve EM4'te çevirmenler tarafından sırasıyla [kız, kızoğlankız ve bakire] şeklinde çevrilirken, EM3’te değiştirilmeksizin ve kaynakta olduğu gibi eğik harflerle yazılarak bırakılmıştır.

\section{Şarkı, Türkülerin Çevrilmesi}

Romandaki şarkı ve türküler çevirmenler tarafından aşağıdaki Tablo 6.'da verildiği şekilde Türkçeye aktarılmıştır.

\begin{tabular}{|c|c|c|c|c|}
\hline KM (1898) & EM1 (1922) & EM2 (1940) & $\begin{array}{l}\text { EM3 } \\
(1959 / 1989 / 2012)\end{array}$ & EM4 (1962) \\
\hline $\begin{array}{l}\text { Dime, niña, si me } \\
\text { quieres ; } \\
\text { Por Dios, descubre tu } \\
\text { pecho... } \\
\text { Petite aux vingt novios } \\
\text { (Et avec moi vingt et } \\
\text { un), } \\
\text { Si tous sont comme je }\end{array}$ & $\begin{array}{l}\text { Sen beni ister } \\
\text { misin? Gel söyle, } \\
\text { Allah aşkına! } \\
\text { Merhamet kıl! } \\
\text { Göğsünü aç şöyle, } \\
\text { Allah aşkına! } \\
\text { Yirmi âşık peykte } \\
\text { gezmekte }\end{array}$ & $\begin{array}{l}\text { Dime mina si me } \\
\text { kiere; } \\
\text { Por Dios descubre } \\
\text { tu pecho } \\
\text { Yirmi dostlu } \\
\text { yavrum, } \\
\text { (Benle oldu yirmi } \\
\text { bir), }\end{array}$ & $\begin{array}{l}\text { Dime, nina, si me } \\
\text { quieres; } \\
\text { Por Dios, descubre tu } \\
\text { pecho... } \\
\text { Yirmi noviolu } \\
\text { haspa } \\
\text { (Ben de varm; yirmi } \\
\text { bir), }\end{array}$ & $\begin{array}{l}\text { Dime, nina, si me } \\
\text { quires; } \\
\text { Por Dios, } \\
\text { descubre tu } \\
\text { uecho... } \\
\text { Yirmi aşılklı kız, } \\
\text { (Ve benimle yirmi } \\
\text { bir), }\end{array}$ \\
\hline
\end{tabular}


Turkish translations of multilingualism in the context of illustrated travel literature: La Femme et Le Pantin, roman espagnol / A. Özkan; O. Çeviktay (pp. 471-489)

\begin{tabular}{|c|c|c|c|c|}
\hline $\begin{array}{l}\text { suis, } \\
\text { Tu resteras toute seule. } \\
\text { (s.23) }\end{array}$ & $\begin{array}{l}\text { Onlara bir de } \\
\text { dâhil oldum ben } \\
\text { Bana bakarsa ah, } \\
\text { yirmisi de, } \\
\text { O zaman pek } \\
\text { açıkta kaldın sen. } \\
\text { (s.43) }\end{array}$ & $\begin{array}{l}\text { Hepsi benim gibi } \\
\text { ise, } \\
\text { Yalnız kalırsın } \\
\text { yavrum. (s.29) }\end{array}$ & $\begin{array}{l}\text { Hepsi benim gibiyse, } \\
\text { Kalursin tek başına. } \\
\text { (s.28/37/39) }\end{array}$ & $\begin{array}{l}\text { Eğer hepsi benim } \\
\text { gibiyse } \\
\text { Yapayalnız } \\
\text { kalırsın. } \\
\text { (s.25-26) } \\
\text { (İspanyolca } \\
\text { sözlerdeki imla } \\
\text { değişiklikleri } \\
\text { EM4'e aittir.) }\end{array}$ \\
\hline 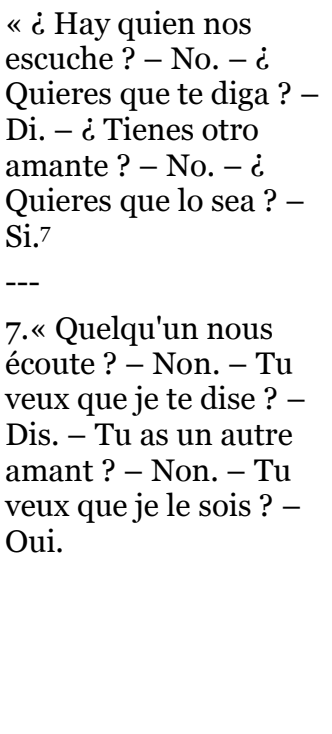 & $\begin{array}{l}\text { “-Bilemem, kimse } \\
\text { dinliyor mu bizi? } \\
\text {-Kimse yok, } \\
\text { Hayır. - } \\
\text { Söyleyeyim mi } \\
\text { sana? } \\
\text {-Söyle. -Dostun } \\
\text { senin acep var mı? } \\
\text {-Hayır. - Dostun } \\
\text { olur muyum } \\
\text { acaba? } \\
\text {-Ne demek? - } \\
\text { Redde bir sebep } \\
\text { var mı?” (s.6o) }\end{array}$ & $\begin{array}{l}\text { Haykien nos } \\
\text { tscuche? - Non (1) } \\
\text { Kieres ke te diga? - } \\
\text { Di } \\
\text { Tienes otre amante? } \\
\text {-No. } \\
\text { Kieres ke io sea? -Si. } \\
\text {--- } \\
\text { (1) -Bizi kimse } \\
\text { dinliyor mu? - } \\
\text { Hayır. } \\
\text { - Söylediğimi istiyor } \\
\text { musun? - Söyle. } \\
\text { - Başka bir âşıkın } \\
\text { var mı? -Hayır. } \\
\text { - Ben o âşıkın } \\
\text { olayım mı? - Evet. } \\
\text { (s.40) }\end{array}$ & $\begin{array}{l}\text { "Dinleyen var mı } \\
\text { bizi? - Yok } \\
\text { - Söyleyeyim mi } \\
\text { sana? - Söyle } \\
\text { - Başka sevgilin var } \\
\text { mı? - Yok } \\
\text { - Ben olayım mı } \\
\text { sevgilin? - Evet. } \\
\text { (s.39/46/51) }\end{array}$ & $\begin{array}{l}\text { Hay quien nos } \\
\text { escuche ? - No. } \\
\text { (Bizi dinleyen var } \\
\text { mı? - Hayır) } \\
\text { Quieres que te } \\
\text { diga ? - Di. } \\
\text { (Sana söyleyeyim } \\
\text { mi? - Söyle.) } \\
\text { Tienes otro } \\
\text { amante? - No. } \\
\text { (Basska aşığın var } \\
\text { mı? - Hayır.) } \\
\text { Quieres que lo sea } \\
\text { ? - Si. (Aşığın ben } \\
\text { olayım mı? - } \\
\text { Evet.) } \\
\text { (s.36) }\end{array}$ \\
\hline
\end{tabular}

Tablo 6. Şarkı ve türkülerin çevrilmesi

Romandaki kadın kahramanın (Concha Perez) söylediği İspanyolca şarkıların çevirisinin verildiği tablodaki ilk sıradaki örnekte, EMı'de İspanyolca olan şarkı Türkçeye aktarılmıştır. Bununla birlikte, EM2, EM3 ve EM4’te İspanyolca metin çevrilmeden bırakılmıştır. Aynı örneğin Fransızca olan kısmındaki “novio” ifadesi ise EM1, EM2 ve EM4’te çevirmenler tarafından sırasıyla [âşık, dost ve âşık] şeklinde çevrilirken, EM3’te KM’deki şekliyle bırakılmıştır. Son sıradaki örnekte bulunan İspanyolca şarkının KM'de dipnot olarak Fransızcası verilmiştir. EM1 ve EM3’te çevirmenler İspanyolca şarkıyı dipnottaki açıklamasında buldukları Fransızcası üzerinden Türkçeye çevirmiştir. EMə'de çevirmen İspanyolca şarkıyı kaynak metinde yazıldığı gibi değil, ancak /q/ sesinin bulunduğu yerlerde $k$ harfi kullanarak ve başka yerlerde de tapaj hatalarıyla yazmış ve dipnot koyup Fransızca açıklamayı Türkçeye çevirmiştir. EM4’te ise İspanyolca şarkı aynen bırakılmış, Fransızca dipnot parantez içlerinde metne eklenerek çevrilmiştir.

\section{Dipnotların çevrilmesi}

Dipnot çevirilerinin incelenmesinde, kaynak metinde mevcut ve erek metne aktarlan dipnotlar ile kaynak metinde bulunmayıp, erek metne çevirmen notu olarak eklenen dipnotlar olmak üzere iki tür dipnot gözlenmiştir. Kaynak metinde bulunan dipnotların çevrilmesi Tablo 7'de, çevirmen notları ise Tablo 8'de verilmiştir. 


\begin{tabular}{|c|c|c|c|c|}
\hline KM (1898) & EM1 (1922) & EM2 (1940) & $\begin{array}{l}\mathrm{EM} 3 \\
(1959 / 1989 / 2012)\end{array}$ & $\mathrm{EM}_{4}$ (1962) \\
\hline $\begin{array}{l}\text { "Concepcion, } \\
\text { Concha, Conchita, } \\
\text { Chita1. " }^{1} \text { 1. Prononcer: } \\
\text { Conntcha, } \\
\text { Conntchita, etc. } \\
\text { (s.11) }\end{array}$ & $\begin{array}{l}\text { "Konsepsiyon, Konça, } \\
\text { konçita, çita [1]" } \\
\text { diyordu. } \\
\text { (1) Surasına göre } \\
\text { sunh yahut saniha } \\
\text { manasına gelen } \\
\text { Konsepsiyon'un ism-i } \\
\text { tasgirleridir. (s.20) }\end{array}$ & $\begin{array}{l}\text { “Konsepsion, } \\
\text { Konça, Konçita, } \\
\text { Çita...” (s.15) } \\
\text {--- } \\
\text { Metinde yer } \\
\text { almamaktadır. }\end{array}$ & $\begin{array}{l}\text { "Concepcion, Concha, } \\
\text { Conchita, Chita }{ }^{1} \text {." } \\
-- \\
1 \text { Konça, Konçita } \\
\text { okuyun. (s.13/22/22) }\end{array}$ & $\begin{array}{l}\text { "Concepcion, } \\
\text { Concha, Conchita, } \\
\text { Chita." (s.12) } \\
\text {--- } \\
\text { Metinde yer } \\
\text { almamaktadır. }\end{array}$ \\
\hline $\begin{array}{l}\text {... qu'elle n'avait pas } \\
\text { de novio² et qu'on } \\
\text { l'appelait Concha } \\
\text { Perez. } \\
\text {-- } \\
\text { 2.Novio, et le féminin } \\
\text { novia, correspondent } \\
\text { exactement à ce que } \\
\text { les ouvriers français } \\
\text { appellent une } \\
\text { connaissance. C'est } \\
\text { un mot délicat en } \\
\text { ceci qu'il ne préjuge } \\
\text { rien et qu'il désigne à } \\
\text { volonté l'amitié, } \\
\text { l'amour ou le plus } \\
\text { simple concubinage. } \\
\text { (s. 22) }\end{array}$ & $\begin{array}{l}\text {... asşı̆̆ı, dostu yoktu; } \\
\text { ismi de Konça Perez } \\
\text { idi. (s.42) } \\
\text {--- } \\
\text { Metinde yer } \\
\text { almamaktadır. }\end{array}$ & $\begin{array}{l}\text {...Novio (1) su } \\
\text { olmadığını ve } \\
\text { adının da Konşa } \\
\text { Perez olduğunu } \\
\text { öğrenmişti. } \\
\text {--- } \\
\text { (1) Novio ve } \\
\text { müennesi olan } \\
\text { Novia Fransız } \\
\text { amelesinin ahbap } \\
\text { dedikleri kelimenin } \\
\text { mukabilidir. Bu } \\
\text { kelimenin haddi } \\
\text { zatında muayyen } \\
\text { bir mânâsı yoktur. } \\
\text { Dostluk, aşk, } \\
\text { orospuluk gibi } \\
\text { istenildiği gibi } \\
\text { mânâya gelir. } \\
\text { (s.28) }\end{array}$ & $\begin{array}{l}\text {...novio'su (1) } \\
\text { olmadığını, adının } \\
\text { Concha Perez } \\
\text { olduğunu... } \\
\text {--- } \\
\text { 1. Sevgili aftos (1959- } \\
\text { 27) } \\
\text { 1. Novio sevgili } \\
\text { anlamına gelir. Hiçbir } \\
\text { önyargı içermemesi, } \\
\text { dostluk, aşk ya da } \\
\text { yalnızca bir arada } \\
\text { yaşamayı belirtmesi } \\
\text { açısından ince bir } \\
\text { sözcüktür. (1989, } \\
\text { s.36; 2012, s.38) }\end{array}$ & $\begin{array}{l}\text {...sevgilisi } \\
\text { olmadığını, adının } \\
\text { Concha Perez } \\
\text { olduğunu } \\
\text { biliyordu. (s.25) } \\
\text { Metinde yer } \\
\text { almamaktadır. }\end{array}$ \\
\hline $\begin{array}{l}\text {...un grand escogriffe } \\
\text { vêtu d'un uniforme } \\
\text { de garde civil3 } \\
\text {--- } \\
\text { 3. Gendarme } \\
\text { espagnol (s.24) }\end{array}$ & $\begin{array}{l}\text {...bir jandarma } \\
\text { göründü, kocaman } \\
\text { çizmeleriyle bölme } \\
\text { üzerine atladı. (s.45) } \\
\text { Metinde yer } \\
\text { almamaktadır. }\end{array}$ & $\begin{array}{l}\text {...kompartımandan } \\
\text { jandarma } \\
\text { üniformalı iri bir } \\
\text { herif... (s.30) } \\
\text { Metinde yer } \\
\text { almamaktadır. }\end{array}$ & $\begin{array}{l}\text { Her şey yatıştıktan } \\
\text { sonra, jandarma } \\
\text { elbisesi giymiş iri yarı } \\
\text { bir herif... } \\
\text { (s.29/38/40) } \\
\text { Metinde yer } \\
\text { almamaktadır. }\end{array}$ & $\begin{array}{l}\text {..., iri yapıll, çirkin } \\
\text { yüzlü bir } \\
\text { jandarma } \\
\text { meydana çıtı. } \\
\text { (s.27) } \\
\text { Metinde yer } \\
\text { almamaktadır. }\end{array}$ \\
\hline $\begin{array}{l}\text { Une aprèsmidi, par } \\
\text { désœuvrement, } \\
\text { j'entrai à la } \\
\text { Fábrica4. } \\
\text {--- } \\
\text { 4. La manufacture de } \\
\text { tabacs en Séville. } \\
\text { (s.27) }\end{array}$ & $\begin{array}{l}\text {...yapacak bir şey } \\
\text { bulamadığım için } \\
\text { Eşbiliye tütün } \\
\text { fabrikasına girdim. } \\
\text { (s.52) } \\
\text { Metinde yer } \\
\text { almamaktadır. }\end{array}$ & $\begin{array}{l}\text { Bir gün öğleden } \\
\text { sonra işsizlikten } \\
\text { slkılarak fabrika } \\
\text { (1)ya girdim. } \\
\text {--- } \\
\text { (1) Sevil'de sigara } \\
\text { yapllan mahal } \\
\text { (s.35) }\end{array}$ & $\begin{array}{l}\text { Bir öğle sonu can } \\
\text { slkıntısından } \\
\text { Fabrikaya (1) girdim. } \\
\text { (1) Tütün fabrikası. } \\
\text { 1959 (s.33) } \\
\text { (1) Sevilla'da tütün } \\
\text { fabrikası. (s.42/s.46) }\end{array}$ & $\begin{array}{l}\text { Bir gün öğleden } \\
\text { sonra can } \\
\text { slkıntısını } \\
\text { defetmek için } \\
\text { tütün } \\
\text { fabrikasına } \\
\text { girdim. (s.30) } \\
\text { Metinde yer } \\
\text { almamaktadır. }\end{array}$ \\
\hline $\begin{array}{l}\text { «...si vous me donnez } \\
\text { une perra chica }{ }^{5} . . \\
\text { 5. Un sou. (s.29) }\end{array}$ & $\begin{array}{l}\text {-... bana on para verir } \\
\text { misiniz? (s.56) } \\
\text { Metinde yer } \\
\text { almamaktadır. }\end{array}$ & $\begin{array}{l}\text {... bana bir "perra } \\
\text { chika" verirsen ... } \\
\text { (s.37) } \\
\text { Metinde yer } \\
\text { almamaktadır. }\end{array}$ & $\begin{array}{l}\text {...bana, bir perra } \\
\text { chica (1) verirseniz, } \\
\text { (1) Bir kuruş. } \\
\text { (s.36/44/48) }\end{array}$ & $\begin{array}{l}\text {...bana bir kuruş } \\
\text { verirseniz, ... } \\
\text { (s.33) } \\
\text { Metinde yer } \\
\text { almamaktadır. }\end{array}$ \\
\hline $\begin{array}{l}\text { - Eh bien, donnez- } \\
\text { moi un réal6 ... } \\
\text { 6. Cinq sous. } \\
\text { (s.29-30) }\end{array}$ & $\begin{array}{l}\text { Haydi görelim, bana } \\
\text { bir riyal [1] veriniz... } \\
\text { [1] Bir İspanyol riyali } \\
\text { takriben gümüş elli } \\
\text { para klymetindedir. } \\
\text { (s.56) }\end{array}$ & $\begin{array}{l}\text { Hadi bir riyal ver! } \\
\text {.... (s.38) } \\
\text { Metinde yer } \\
\text { almamaktadır }\end{array}$ & $\begin{array}{l}\text { Haydi bakalım, bana } \\
\text { bir réal verin (2)... } \\
\text { (2) Beş kuruş. } \\
\text { (s.36/44/48) }\end{array}$ & $\begin{array}{l}\text { Bana beş kuruş } \\
\text { verin, ... (s.33) } \\
\text { Metinde yer } \\
\text { almamaktadır. }\end{array}$ \\
\hline $\begin{array}{l}\text { - Je suis mozita }{ }^{8} » \\
\text { 8.Mozita est un mot }\end{array}$ & $\begin{array}{l}\text { - Kız oğlan kızım. } \\
\text { (s.61) }\end{array}$ & $\begin{array}{l}\text {-Kızoğlankızım } \\
\text { (s.41) }\end{array}$ & $\begin{array}{l}\text { - Ben mozita'yım } \\
\text { (1). }\end{array}$ & $\begin{array}{l}\text { - Bakireyim } \\
\text { (s.37) }\end{array}$ \\
\hline
\end{tabular}


Turkish translations of multilingualism in the context of illustrated travel literature: La Femme et Le Pantin, roman espagnol / A. Özkan; O. Çeviktay (pp. 471-489)

\begin{tabular}{|c|c|c|c|c|}
\hline $\begin{array}{l}\text { plus familier que } \\
\text { Virgen, et que les } \\
\text { jeunes filles } \\
\text { emploient plus } \\
\text { librement pour } \\
\text { exprimer qu'elles } \\
\text { sont restées pures. Le } \\
\text { mot français qui } \\
\text { traduit la même } \\
\text { nuance est } \\
\text { aujourd'hui } \\
\text { déconsidéré. (s.49) }\end{array}$ & $\begin{array}{l}\text { Metinde yer } \\
\text { almamaktadır }\end{array}$ & $\begin{array}{l}\text { Metinde yer } \\
\text { almamaktadır. }\end{array}$ & $\begin{array}{l}\text { (1) Bakire, temiz } \\
\text { kalmış. } \\
\text { 1959 (s.40) } \\
\text { (1) Mozita } \\
\text { virgenden daha } \\
\text { teklifsiz bir sözcüktür. } \\
\text { Genç kızlar arı } \\
\text { kaldıklarını belirtmek } \\
\text { için bu sözcüğ̈u } \\
\text { rahatlıkla kullanırlar. } \\
\text { Aynı ayrımı belirten } \\
\text { Fransızca sözcük } \\
\text { bugün saygınlığını } \\
\text { yitirmiştir.(s.47/51) }\end{array}$ & $\begin{array}{l}\text { Metinde yer } \\
\text { almamaktadır }\end{array}$ \\
\hline $\begin{array}{l}\text { On l'appelait le } \\
\text { Morenito9. ... } \\
\text { 9. « Le petit brun. » } \\
\text { (s.59) }\end{array}$ & $\begin{array}{l}\text {..."morenito" diye } \\
\text { çağırıyorlardı. } \\
\text { 1. İspanyolca "küçük } \\
\text { esmer" manasına gelir. } \\
\text { (s.115) }\end{array}$ & $\begin{array}{l}\text { Lakabı Morenito } \\
\text { (1) olan... } \\
\text {-- (1) küçük esmer } \\
\text { demektir. } \\
\text { (s.74-75) }\end{array}$ & $\begin{array}{l}\text { Morenito [1] } \\
\text { diyorlardı ona, } \\
\text { (1) Küçük esmer. } \\
\text { (s.73/82/88) }\end{array}$ & $\begin{array}{l}\text { Herkes ona } \\
\text { "Morenito"(*) } \\
\text { diye... } \\
\text { (*) Küçük esmer. } \\
\text { (s.69) }\end{array}$ \\
\hline $\begin{array}{l}\text { - ...Elle montre son } \\
\text { nombril à des } \\
\text { Inglès }{ }^{10} \text {. } \\
\text {--- } \\
\text { 1o.Le mot Inglès } \\
\text { (Anglais) désigne } \\
\text { tous les étrangers, en } \\
\text { Espagne. (s.61) }\end{array}$ & $\begin{array}{l}\text { Yukarıda birkaç } \\
\text { "Inglez”[2] var,...--- } \\
\text { [2] Bu kelime } \\
\text { İspanyolca İngiliz } \\
\text { demektir. Lakin } \\
\text { herhangi milletten } \\
\text { olursa olsun ecnebileri } \\
\text { göstermek için } \\
\text { kullanılır. Bizde } \\
\text { muadili olan "frenk" } \\
\text { gibi. (s.113) }\end{array}$ & $\begin{array}{l}\text {...İngilizlere } \\
\text { göbeğini } \\
\text { gösteriyor. (s.76) } \\
\text { Metinde yer } \\
\text { almamaktadır. }\end{array}$ & $\begin{array}{l}\text {...Inglèslere [1] } \\
\text { göbeğini gösteriyor. } \\
\text { (1) İspanya'da Inglès } \\
\text { (İngiliz) kelimesi } \\
\text { ecnebi anlamında } \\
\text { kullanılır. } \\
\text { 1959 (s.75) } \\
\text { (1) İspanya'da Inglès } \\
\text { (İngiliz) sözcüğ̈u } \\
\text { bütün yabancıları } \\
\text { belirtir. (s.84/9o) }\end{array}$ & $\begin{array}{l}\text {.... Yukarda } \\
\text { Ingilizlere } \\
\text { göbeğini } \\
\text { gösteriyor. (s.71) } \\
\text { Metinde yer } \\
\text { almamaktadır. }\end{array}$ \\
\hline $\begin{array}{l}\text {..., je choisis pour elle } \\
\text { un palacio'11 ... } \\
\text {--- } \\
\text { 11.Hôtel privé. (s.69) }\end{array}$ & $\begin{array}{l}\text {...hususi bir hane } \\
\text { intihap ve isticar ettim. } \\
\text { (s.128) } \\
\text { Metinde yer } \\
\text { almamaktadır. }\end{array}$ & $\begin{array}{l}\text {... bir "palacio" (1) } \\
\text { intihap ettim. } \\
\text { (1) İspanyolca } \\
\text { konak demektir. } \\
\text { (s.88) }\end{array}$ & $\begin{array}{l}\text {...bir konak seçtim. } \\
\text { Metinde yer } \\
\text { almamaktadır. } \\
\text { (s. 85/96/102) }\end{array}$ & $\begin{array}{l}\text { güzel bir köşk } \\
\text { seçtim. (s.82) } \\
\text { Metinde yer } \\
\text { almamaktadır. }\end{array}$ \\
\hline $\begin{array}{l}\text {... la grille'12 était } \\
\text { fermée aux barres. } \\
\text {--- } \\
\text { 12. Les maisons } \\
\text { espagnoles sont } \\
\text { fermées par une } \\
\text { grille à travers } \\
\text { laquelle on voit, au- } \\
\text { delà d'un large } \\
\text { passage, le patio, } \\
\text { cour intérieure d'une } \\
\text { architecture très } \\
\text { ornée, avec une } \\
\text { fontaine et des } \\
\text { plantes vertes. }\end{array}$ & $\begin{array}{l}\text {...demir parmaklıklı } \\
\text { kapı muhkemce sedd } \\
\text { edilmişti [1]. } \\
\text { [1] İspanya'da evlerin } \\
\text { sokak kapıları } \\
\text { umumiyetle demir } \\
\text { parmaklıklıdır. } \\
\text { Aralıktan evin havalisi } \\
\text { ve alelade fiskiyelerle } \\
\text { müzeyyen bir seddi } \\
\text { görülür. Her İspanyol } \\
\text { evinde yazın kameriye } \\
\text { hizmetini gören böyle } \\
\text { çardaklı birer set inşası } \\
\text { adettir. Bu gibi setlere } \\
\text { (patio) derler. } \\
\text { s.129 }\end{array}$ & $\begin{array}{l}\text {... Parmaklığa (2) } \\
\text { kol demiri } \\
\text { vurulmuştu. } \\
\text { [2] İspanyol evleri } \\
\text { umumiyetle demir } \\
\text { bir parmaklıkla } \\
\text { kapanır. Bir } \\
\text { koridordan evin } \\
\text { ortasında bir havuz } \\
\text { ve yeşil nebatlarla } \\
\text { süslü oymalarla } \\
\text { müzeyyen bir tarzı } \\
\text { mimaride yapılmış } \\
\text { iç avlu görünür. } \\
\text { s.88 }\end{array}$ & $\begin{array}{l}\text {...parmaklıklı avlu } \\
\text { kapısı demir } \\
\text { çubuklarla... (1959, } \\
\text { s.86) Metinde yer } \\
\text { almamaktadır. } \\
\text {...parmaklıklı avlu } \\
\text { kapısı demir } \\
\text { çubuklarla } \\
\text { kapanmıştı1. } \\
\text { (1) İspanyol evleri } \\
\text { parmaklıklı bir } \\
\text { kapıyla kapanır. } \\
\text { Parmaklıklar } \\
\text { arasindan geniş bir } \\
\text { geçitin ötesinde, } \\
\text { patio, bir çeşme ve } \\
\text { yeşil bitkiler, çok } \\
\text { süslü bir iç avlu } \\
\text { görünür. (s.97/103) }\end{array}$ & $\begin{array}{l}\text { Demir } \\
\text { parmaklıklı } \\
\text { kapı sımsıkı } \\
\text { kapalıydı. (s.83) } \\
\text { Metinde yer } \\
\text { almamaktadır. }\end{array}$ \\
\hline
\end{tabular}

Tablo 7. Kaynak metinde bulunan dipnotların çevrilmesi

KM'de toplam 12 dipnot bulunmaktadır. Çevirmenlerin bu dipnotları çevirme konusunda farklı eylemleri olmuştur. Tabloda ilk sırada sunulan örnekte roman kahramanın adının nasıl okunacağını gösteren dipnot EM4’te yok sayılırken, EM3’te çevirmen bu çeviriyi yapmıştır. EM2'de dipnot 
çevrilmemiş ve adlar dipnotun içeriğinin işaret ettiği gibi Türkçe okunuşlarıyla yazılmıştır. EM1'de ise çevirmen Osmanlı Türkçesinde isimler okunduğu gibi yazıldı ̆̆ından, dipnotu okunuşları gösteren bir dipnot yerine küçültme isimlerini açlklayan bir dipnot şeklinde çevirmiştir. Dipnotla açıklanan [novio] sözcüğü, EM1'de dipnottaki bilgi kullanılarak [aşı̆̆ı, dostu] şeklinde iki sözcükle karşılanmıştır. EM2'de dipnot çevrilmiştir. EM3'te çevirmen 1959'daki çevirisinde bir çevirmen notu koyarak [sevgili, aftos] şeklinde açıklama yapmış, sonraki çevirilerinde ise KM'deki dipnotu çevirmiştir. EM4'te çevirmen dipnotu metnine almayıp sözcüğ̈̈ [sevgili] şeklinde çevirmiştir.

KM'deki dipnotlardan bir diğeri [garde civil]dir ve açıklamasında İspanyol jandarması yazmaktadır. Bütün çevirmenler bu dipnotu çevirmemeyi tercih edip jandarma şeklinde Türkçeye aktarmışlardır. KM'de dipnotla açıklanan İspanyolca [La Fábrica] dipnotu EM1'de dipnot olarak çevrilmeyip, metne alınmıştır ve İspanyolca gösterge silinmiştir. EM2'de ise bu dipnot çevrilmiştir. EM3’te çevirmen KM'deki bu dipnotu 1959'daki çevirisinde [tütün fabrikası], sonraki çevirilerinde [Sevilla'daki tütün fabrikası] şeklinde çevirmiştir. EM4'te çevirmen bu ifadeyi dipnot olarak çevirmeyip içeriğini [tütün fabrikası] şeklinde metnine aktarmıştır. KM'de beşinci sırada yer alan dipnot [une perra chica] sözcüğünün Fransız para birimi karşılığını (un sou) gösterir. EM1'de bu ifade metnin içinde dipnot kullanmadan [on para] diye çevrilmiştir. EM2'de de dipnot kullanılmadan [perra chika] olarak aktarılmıştır. EM3’te çevirmen dipnot ile [perra chica] için [bir kuruş] karşılığını vermiştir. EM4’te [perra chica] sözcüğü çevrilmeden ve dipnot verilmeden metnin içinde [bir kuruş] şeklinde verilmiştir. KM'deki altıncı dipnot [réal] sözcüğünün Fransız para birimi (cinq sous) karşllı̆̆dır. EMı'de sözcük metinde dipnot kullanılarak Osmanlı para birimine göre açılanmıştır. EM2'de çevirmen dipnot kullanmadan [riyal] şeklinde çevirmiştir. EM3’te çevirmen dipnot açıklamasında Türk para birimi kuruşu tercih ederek [5 kuruş] şeklinde aktarırken, EM4'te çevirmen dipnotu metne almayıp İspanyolca göstergeyi atarak, yerine [5 kuruş] ifadesini kullanarak çevirmiştir.

KM'de yer alan 7. dipnot şarkı ve türkülerin çevirisi kısmındaki tabloda yer aldığı için bu tabloda tekrar gösterilmemiştir. KM'deki 8. dipnot olan [mozita] sözcügü sadece EM3'te KM'de olduğu gibi dipnot olarak verilirken, EM1, EM2 ve EM4'te çevirmenler dipnotu metinlerine almayı sözcügü sırasıyla [kızoğlankızım, kızoğlankızım ve bakireyim] şeklinde çevirmiştir. KM'deki 9. dipnotta [morenito] sözcüğü [le petit brun] (küçük esmer) olarak açılanmıştır. EM1'de çevirmen [morenito] nun hangi dilde olduğu bilgisini ekleyip, İspanyolca'da [küçük esmer] manasına geliyor diyerek aktarmıştır. EM2, EM3 ve EM4'te çevirmenler morenito sözcüğünü metin içerisinde kullanıp dipnot ile [küçük esmer] diyerek çevirmişlerdir. KM'de [Inglès] sözcüğü için 10. dipnotta verilen açılama EM1'de erek kültürdeki karşılığına gönderme yapılarak çevrilmiştir. EM2 ve EM4'te ise çevirmenler dipnotu çevirmeyip [İngilizler] şeklinde aktarmışlardır. EM3'te çevirmen tüm çevirilerinde dipnotu Türkçeye aktarırken, dipnotta 1959'daki çevirisinde kullandığı [ecnebileri] sözcüğü yerine sonraki çevirilerinde [tüm yabancıları] ifadesini kullanmıştır.

KM’deki 11. dipnot ile verilen İspanyolca [palacio] sözcügünün açılamasında tüm çevirmenler farklı tercihler kullanmıştır. EMı'de dipnottaki [hôtel privé] açıklaması dipnot verilmeyerek erek metne [hususi bir hane] şeklinde aktarılmıştır. EM2'de ise bu dipnot [İspanyolcada konak demektir] şeklinde çevrilirken, EM3 ve EM4'te dipnot olarak yer verilmeyerek sözcük sırasıyla [konak ve güzel bir köşk] şeklinde Türkçeye aktarılmıştır. KM'deki 12. dipnot [la grille] sözcüğü içindir. Yazar bu dipnotta İspanyol evlerini betimlemektedir. EM1 ve EM4’te çevirmenler [la grille] sözcüğünü [demir parmaklıklı kapı] şeklinde çevirmiş, ancak EM4'te çevirmen dipnot kullanmazken, EM1'de çevirmen dipnotu Türkçeye aktardığı gibi, içinde geçen [patio] sözcüğünü de açımlamıştır. EM2'de çevirmen [la grille] için parmaklık sözcüğünü tercih edip dipnotu da çevirmiştir. EM३3’te çevirmen söz konusu 
Turkish translations of multilingualism in the context of illustrated travel literature: La Femme et Le Pantin, roman espagnol / A. Özkan; O. Çeviktay (pp. 471-489)

sözcüğü [parmaklıklı avlu kapısı] şeklinde çevirirken, 1959 yılındaki çevirisinde dipnot vermemiş, diğer çevirilerinde ise KM’deki dipnotu çevirmiştir.

\section{Çevirmenlerin ekledikleri çevirmen notları}

Romanda bulunmamasına rağmen çevirmenlerin açıklama getirmek üzere kullandıkları çevirmen notları Tablo 8'de listelenmiştir.

\begin{tabular}{|c|c|c|c|c|}
\hline KM (1898) & EM1 (1922) & EM2 (1940) & $\begin{array}{l}\text { EM3 } \\
(1959 / 1989 / 2012)\end{array}$ & EM4 (1962) \\
\hline $\begin{array}{l}\text { - Faites passer } \\
\text { ma carte à la } \\
\text { señora. (s.9) }\end{array}$ & $\begin{array}{l}\text { - Kartımı sinyora[1] ya } \\
\text { takdim ediniz. } \\
\text { (1) "Sinyora" kelimesi } \\
\text { İspanyollarda "madam" } \\
\text { makamındadır. (s.15) }\end{array}$ & $\begin{array}{l}\text { Metinde yer } \\
\text { almamaktadır }\end{array}$ & $\begin{array}{l}\text { Metinde yer } \\
\text { almamaktadır }\end{array}$ & $\begin{array}{l}\text { Metinde yer } \\
\text { almamaktadır }\end{array}$ \\
\hline $\begin{array}{l}\text {...une somme de } \\
\text { mille douros } \\
\text { pour payer... } \\
\text { (s.52) }\end{array}$ & $\begin{array}{l}\text {... bin "doro" [1] } \\
\text { almıştı;... } \\
\text { [1] doro, takriben yirmi } \\
\text { beş kuruş kiymetinde } \\
\text { gümüş sikkedir. (s.98) }\end{array}$ & $\begin{array}{l}\text { Metinde yer } \\
\text { almamaktadır }\end{array}$ & $\begin{array}{l}\text { Metinde yer } \\
\text { almamaktadır }\end{array}$ & $\begin{array}{l}\text { Metinde yer } \\
\text { almamaktadır }\end{array}$ \\
\hline $\begin{array}{l}\text { J'entrai un soir } \\
\text { dans le Baile de } \\
\text { là-bas. (s.54) }\end{array}$ & $\begin{array}{l}\text { Metinde yer } \\
\text { almamaktadır. }\end{array}$ & $\begin{array}{l}\text { Bir akşam oranın } \\
\text { Baile (1) ine girdim. } \\
\text { (s.68) } \\
\text { 1. Bizdeki eski } \\
\text { balozlar tarzında bir } \\
\text { avam balosu. }\end{array}$ & $\begin{array}{l}\text { Metinde yer } \\
\text { almamaktadır. }\end{array}$ & $\begin{array}{l}\text { Metinde yer } \\
\text { almamaktadir. }\end{array}$ \\
\hline $\begin{array}{l}\text { Elle achevait son } \\
\text { boléro dans un } \\
\text { mouvement de } \\
\text { passion furieuse. } \\
\text { (s.54) }\end{array}$ & $\begin{array}{l}\text { Metinde yer } \\
\text { almamaktadır. }\end{array}$ & $\begin{array}{l}\text { (Bolero) (1) sunu } \\
\text { şiddetli bir aşk } \\
\text { harekatı ile bitiriyor... } \\
\text { (s.69) } \\
\text { 1. Bir nevi dans. }\end{array}$ & $\begin{array}{l}\text { Metinde yer } \\
\text { almamaktadır. }\end{array}$ & $\begin{array}{l}\text { Metinde yer } \\
\text { almamaktadır. }\end{array}$ \\
\hline $\begin{array}{l}\text {..dansaient une } \\
\text { jota forcenee } \\
\text { devant... (s.61) }\end{array}$ & $\begin{array}{l}\text { Metinde yer } \\
\text { almamaktadır. }\end{array}$ & $\begin{array}{l}\text {... delicesine bir jota } \\
\text { (1)oynuyordu. (s.77) } \\
\text { 1. Bir nevi dans. }\end{array}$ & $\begin{array}{l}\text { Metinde yer } \\
\text { almamaktadır. }\end{array}$ & $\begin{array}{l}\text { Metinde yer } \\
\text { almamaktadır. }\end{array}$ \\
\hline $\begin{array}{l}\text {... semblaient } \\
\text { poudrées de cette } \\
\text { fleur délicate qui } \\
\text { embrume la peau } \\
\text { des créoles. (s.7) }\end{array}$ & $\begin{array}{l}\text { Metinde yer } \\
\text { almamaktadır. }\end{array}$ & $\begin{array}{l}\text { Metinde yer } \\
\text { almamaktadır. }\end{array}$ & $\begin{array}{l}\text { Müstemlekelerde } \\
\text { doğmuş beyaz } \\
\text { Avrupalı (1959, s.7) } \\
\text { Sömürgede doğmuş } \\
\text { Avrupalı (1989, s.14; } \\
2012 \text { s.15). }\end{array}$ & $\begin{array}{l}\text { Metinde yer } \\
\text { almamaktadır. }\end{array}$ \\
\hline
\end{tabular}

Tablo 8. Eklenen çevirmen notları

EM1'de KM'de dipnot olarak verilmeyen iki ifade için çevirmen notu eklenmiştir. 1. örnekte [señora] sözcüğü [Sinyora kelimesi İspanyollarda "madam" makamındadır] şeklinde açlklanırken, ikinci örnekte [mille douros] ifadesi [bin doro] şeklinde çevrilip çevirmen notunda [doro, takriben yirmi beş kuruş kıymetinde gümüş sikkedir] açıklaması yapılmıştır. EM2'de KM'de geçen [Baile] ve [bolero] sözcükleri çeviride aynen bırakılmış ve çevirmen dipnotu ile Türkçe açıklamaları verilmiştir. EM3’te KM'de geçen [Créoles] sözcüğü 1959 çevirisinde [müstemlekede doğmuş Avrupalı] ve 1989 ile 2012 çevirilerinde ise [sömürgede doğmuş Avrupalı] şeklinde çevirmen notu eklenerek çevrilmiştir. 


\section{Sonuç gözlemleri}

Çevirmen kararları ve dayanakları sorgulanarak gerçekleştirilen bu betimleyici çalışmada, araştırma sorusunu "Pierre Louÿs'un La Femme et le Pantin-roman espagnol adlı romandaki dil değiştirimi ve çokdillilik öğelerini çevirmenler neden gözlemlediğimiz şekilde çevirmiş olabilir?” sorusu oluşturmaktaydı. Toury’nin süreç öncesi çeviri normlarını işlettiğimizde, bunda çevirmenlerin ve yine eyleyici olarak yayınevlerinin ön kararlarının belirleyici olduğu söylenebilir.

Cumhuriyet öncesi çeviri geleneğinden gelen Hasan Bedreddin'in 1922 yllında romanı yine bir seyahat ve aşk romanı olarak çevirme gayretinde bulunduğu izlenmektedir. Ancak bu gayreti sadece kaynak metni de resimli olan romanı yine aynı resimleri kullanıp çevirerek gösterdiği söylenebilir. Romanın egzotik havasını yan metinle vermeyi tercih etmiş olabilir. Fransızca olan metnin yanı sıra, İspanyolca olan epigramı da Osmanlı Türkçesine aktarmıştır. İncelememiz ışığında romanın egzotik İspanyol havasını koruma konusunda gayret göstermeyi tercih etmediğgi, yerlileştirici bir çeviri yaptığı söylenebilir. Matriks normlar ve çeviri süreci normları açısından baktığımızda, Hasan Bedreddin özel gün isimlerini erek dizge okuyucusunun anlayabileceği biçimde yerlileştirerek ve/veya açıklayarak çevirmiştir. Bu açıklamaların kiminde kaynak dildeki sözcügü koruduğu görülmektedir. Bazılarında ise doğrudan yerlileştirme stratejisi izlediği görülmüştür. Özel isimleri ve hitapları Türkçe okunduğu şekliyle çevirdiği izlenmiştir. Dolayısıyla yerlileştirme stratejisini tercih ederek erek kültürün normlarına göre bir çeviri yaptıklarını söyleyebiliriz. Betimleyici çalışmalar tarihsel çeviri araştırmalarının önemli bir yapı taşıdır (krş. Bengi-Öner 1999; Paker 2009: 107). Osmanlı edebiyatını çevirileriyle biçimlendiren Hasan Bedreddin'in çevirisini incelediğimizde erek kültür okuyucusunun anlayabileceği, okuyucuyu bilgilendiren bir çeviri yapmayı amaçladığı söylenebilir.

Erken Cumhuriyet döneminde ise Çeviri Bürosu'nun çeviri faaliyetlerine denk gelen bir dönemde 1940'ta çeviriyi yapan Ref'i Cevat Ulunay, Türkçe çeviride resimleri yine kullanmıştır. 1924-1938 döneminde yurtdışında sürgünde olan Ulunay, affedildiği 1938'den sonra yurda döndüğünde merkez edebiyat eserlerinin çevirilerini üreten Tercüme Bürosu çevirmenlerinin aksine çevresel edebiyat ürünlerini çevirmeyi tercih etmiştir. 1940 yılında basılan Kadın ve Oyuncağı çevirisinde Refi Cevat Ulunay'ın kaynak metnin başındaki epigramı çevirmediği, çevirmen notu kullandığı gözlenmiştir. İspanyolca şarkı, türküleri ve isimleri Türkçe okunuşları ile vermesi, dil değiştirimini erek kültürün sesletimine uygun yaptığını göstermektedir. Ayrıca doğrudan anlatımlı ifadeleri İspanyolca bıraktığı gözlenmektedir. Dolaylı anlatımlı ifadelerini İspanyolca kullanmadan erek kültür diline uygun çevirdiği söylenebilir. Bu yönleriyle erek dizgedeki yabancı dilin sesletimi çevirinin bir seyahat romanı olarak alımlanmasını kolaylaştırdığı söylenebilir.

Cumhuriyet dönemi çevirmenlerinden Tahsin Yücel’in çevirileri ise resimleri içermemiştir. Mehmet Doğan Özbay çevirisinde ise yine resimler kullanılmamış, ancak çeviri 1959'da Brigitte Bardot'nun oynadığı romandan uyarlanan aynı adlı filmden sonra yapıldığından ön ve arka kapakta romandaki ve filmdeki erotizm fazlasıyla vurgulanmıştır. Arka kapakta filmde oynayanların adları da yazılıdır.

Tahsin Yücel (1933-2016) edebiyat metinleri çevirisinde erek kültür ve dilde akıcı ve yerlileştirici bir çeviri stratejisi kullanmanın gerekli olmadığı düşüncesini savunmuştur (Ece 2013: 98). Yücel'in 1959 yılındaki Kadın ve Kukla çevirisi matriks normlar açısından 1989 ve 2012 yılı çevirilerinden farklıdır. Romanın başındaki epigram 1959 yılındaki çeviride bulunmazken, 1989 ve 2012 metinlerinde bu İspanyolca epigram Türkçeye çevrilmeden bulunmaktadır. 
Turkish translations of multilingualism in the context of illustrated travel literature: La Femme et Le Pantin, roman espagnol / A. Özkan; O. Çeviktay (pp. 471-489)

Erek metinde görülen yer isimleri, dini gün ve bayram isimleri, şarkılar türküler, hitap şekilleri ve konuşma dili gibi doğrudan anlatımlı ifadelerin söz konusu olduğu bağırış, çağırış haykırışlar gibi kültürel özellikleri belirten İspanyolca ifadelerin ve metnin başındaki İspanyolca epigramın kaynak metindeki dil değiştirimi ve çok dillilik özelliğini aktardığı söylenebilir. Bu çeviri stratejisi Yücel'in edebiyat çevirilerindeki yabancılaştırıcı, kaynak metindeki bağlantıları erek metne aktarabilme yaklaşımına uymaktadır. Dahası, bu çalışmadaki bulgularımız araştırmacıların kendisi üzerine yaptığı araştırmalarla uyumludur. Onun çevirileri kaynak metnin yazarının üslubunu silmek istemeyen; doğallaştırıcı, akıcı çeviri yerine yabancılaştırıcı çeviri yaklaşımını benimseyen bir tarzdaydı (Krş. Ece, 2013: 95). Çevirmen son iki çevirisinde Arapça ve Farsça kökenli sözcükler yerine öz Türkçe sözcükleri tercih etmiştir. Yazarın tüm dipnotlarını çevirmiş ve bir adet de çevirmen notu kullanmıştır. Böylece yazarın oluşturmaya çalıştığı çokdilli ve yabancı havayı korumayı tercih ettiği ve yabancılaştırıı bir strateji kullandığı söylenebilir.

Kadın ve Kuklası (1962) çevirisinde Doğan Özbay İspanyolca ve Fransızca özel isimleri özgün halleriyle bırakmıştır. Çevirmen notu kullanmayıp İspanyolca bazı sözcüklerin anlamlarını yanlarına yazmıştır. İspanyolca türküleri İspanyolca bırakmış, Fransızcaları çevirmiştir. Kaynak metindeki İspanyolca epigramı çevirmemiş ve kaynak metindeki 11 dipnottan sadece bir tanesini çevirmiştir. Seyahat romanı çevirilerindeki tek bir dil olgusunu korumanın getirdiği zorluk (Cronin, 2008: 10) böyle bir tercihe neden olabilir. Arka kapaktaki Brigitte Bardot çizgi figürü doğrudan 1959'da La Femme et le Pantin ismiyle Pierre Louÿs'ten uyarlanan filme yapılmış bir göndermedir. Bu metin dışı öge ile yayınevinin romanın erek okuyucu kitlesi üzerindeki etkisini çoğaltmak istediği gözlenmektedir. Çalışmamıza konu olan çevirinin sonuna eklenen kısaltılmış roman çevirisi, çevirmenin kimi zaman kısaltılmış çeviri yaptığını göstermektedir. Çalışmamızda çevirmenin bir dipnot dışında dipnotları çevirmemeyi tercih ettiği görülmüştür. Romanın başındaki epigram çeviriye alınmamıştır. Çevirmen notu kullanmamıştır. Bağırış çağırış gibi doğrudan anlatım ifadelerinin çevirisinde erek kültürün dilsel dizgesine göre bir çeviri stratejisi tercih etmiştir. İspanyolcaları çevirmeden bırakmıştır. Sadece bir İspanyolca sözcüğün hemen yanına eşittir işareti koyarak Türkçesini yazmıştır.

Resimli seyahat romanındaki çokdilliliğin çevirisine odaklanan çalışmamızda çevirmenlerin eksiltme, metin-içi çeviri yapma, açımlama gibi stratejiler kullandığı görülmüştür. Geç Cumhuriyet dönemi çevirmenlerinin yabancı havayı korumak üzere çift dilliliğe müdahale etmediği, Osmanlı geleneğinden gelen ve erken Cumhuriyet dönemi çevirmenlerinin açımlama ve metin içi çeviri yoluyla yerlileştirmeye çalıştı̆̆ görülmüştür. Ayrıca çevirmen notu kullanarak açımlama yapmışlardır. $\mathrm{O}$ dönem çevirmenlerin görünürlüğünü sağlayan bu eylem okurlar açısından anlaşılırlı̆̆ı da arttırmaktadır. Bu strateji özellikle Ayşe Banu Karadağ’nn (2011) ortaya koyduğu gibi tarihimizde Osmanlı döneminde bir diliçi çeviri olarak dipnot kullanımı geleneği olan şerh ve haşiye düşme geleneğiyle ilişkilendirilebilir (Krş. Karadağ, 2011: 38). Bunun yanı sıra popüler cep romanı biçiminde yapılan çevirinin de açımlama yapma ve dipnotları çevirmeme gibi stratejiler kullanarak yerlileştirici bir yöntem kullandığını söyleyebiliriz. Bu bulgular alanyazında farklı diller arasında ve farklı edebiyat türlerinde yapılmış çalışmalarla karşlaştırıldığında benzer sonuçlara ulaşıldığı görülmektedir. Örneğin Ural'ın (2019: 28) çalışmasında gösterildiği gibi göç romanının çevirisinde erek okuyucu kitlesinin okuma kolaylığını öne çıkaran ve yabancılaştırıcı etkileri geri plana iten çeviriler gözlenmiştir.

Seyahat romanı çevirisi incelemesine örnek teşkil ettiğini düşündüğümüz bu çalışmamızla çeviri edimi ve çevirmen kararları seyahat teması altında dil değiştirimi ve çok dilliliğ̆in aktarımı düzlemlerinde

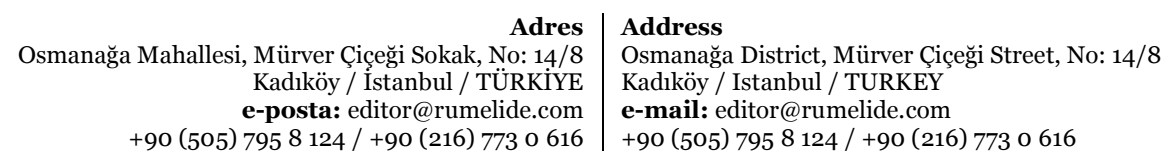


sorgulanmıştır. Sonuç olarak, bir eserin farklı zamanlarda yapılmış çevirilerinin ait oldukları dönemin normlarına uygun olarak, erek kültürdeki farklı ihtiyaçları karşıladığı görülebilir. Çevirmenlerin dönemin çeviri normlarına uygun olarak erek kültürün edebiyat repertuarına katkıda bulunduğu anlaşılmıştır.

\section{Kaynakça}

Anamur, Hasan (2013) Başlangıcından bugüne Fransızcadan Türkçeye yapılmış çeviriler ile Fransız düşünürler, yazarlar, sanatçllar üzerine Türkçe yayınları içeren bir kaynakça denemesi. Gündoğan Yayınları. İstanbul

Bengi-Öner, Işın (1999) Türk Edebiyatında La Dame Aux Camélias Çevirileri. Çeviri Bir Süreçtir Ya Çeviribilim. Forum 2. Sel Yayıncılık. İstanbul. 45-63.

Berman, Antoine (2004) "Çeviri ve çeviri üstüne söylemler" çev. M. Rifat. Çeviri Seçkisi II, Çeviri(bilim) nedir? Dünya Yayınları. İstanbul. 13-23.

Cronin, Michael (2000) Across the Lines Travel, Language, Translation. Cork University Press.

Cronin, Michael (2008) "Downsizing the world: Translation and the politics of proximity". Beyond Descriptive Translation Studies: Investigations in homage to Gideon Toury. Ed. Anthony Pym, Miriam Shlesinger ve Daniel Simeoni. Benjamins Translation Library.

Ece, Ayşe (2013) “Tahsin Yücel ve Çeviri Eylemi”, Dilbilim Dergisi. Cilt 30. Sayı 2. ss.91-100.

Karadă̆, Ayşe Banu (2011) "Bir Diliçi Çeviri Örneği Olarak 'Dipnotlar' ve 'Dipnotlarla Bir Çeviriyi 'Yeniden Yazmak'.” Çeviribilim Dergisi, 8 (2012). ss. 35-40.

López Jiménez, Luis (1997) "Pierre Louÿs, le trompe-Voeil d'une espagnolade érotique" AA. VV. IV Coloquio de la Asociacion de Profesores de Francés de la Universidad Espaňola. Las Palmas. ss 39-52.

Meylaerts, Reine (2013) "Multilingualism as a Challenge for Translation Studies". In C. Millan-Varela \& F. Bartrina (Eds.), Routledge Handbook of Translation Studies. Routledge.

Necatigil, Behçet (2002) Edebiyatımızda İsimler Sözlüğü. İstanbul: Varlık Yayınları

Öncü, Mehmet Tahir (2017) Türkçe Çeviriler Bibliyografyası Dünya Edebiyatından Çeviriler. İstanbul. Hiper Yayın

Paker, Saliha (2002) "Translation as Terceme and Nazire: Culture-bound Concepts and their Implications for a Conceptual Framework for Research on Ottoman Translation History". Crosscultural Transgressions, Research Models in Translation Studies II Historical and Ideological Issues. Theo Hermans (ed). Manchester: UK ve Northampton MA. 120-143.

Polezzi, Loredana (2006) "Translation, Travel, Migration” The Translator. 12:2. 169-188

Simon, Sherry (2002) "Border writing in Quebec". Chapter 3 Translating and interlingual creation in the contact zone, Postcolonial Translation içinde. ed. Susan Bassnet ve Harish Trivedi. Taylor \& Francis e-Library.

Tanyolaç-Öztokat, Nedret (2002) "Sunu”. Söylem Söylen Yazın. Tahsin Yücel'e Armağan. Nedret Tanyolaç Öztokat (yayına hazırlayan) Can Yayınları. İstanbul. 9-15.

Toury, Gideon (1995) Descriptive Translation Studies. John Benjamins Publishing Company. Amsterdam/Philadelphia.

Ural, Gökhan (2019) Analysis of an Immigrant Novel and Its Turkish Translation from the Standpoint of Translation Studies, Yayınlanmamış Yüksek Lisans Tezi. 29 Mayıs Üniversitesi. İstanbul

Venuti, Lawrence (2008) The Translator's Invisibility: A History of Translation. 2.bs. Routledge. London/New York. 